\title{
A Methyl 4-Oxo-4-phenylbut-2-enoate with in Vivo Activity against MRSA that Inhibits MenB in the Bacterial Menaquinone Biosynthesis Pathway
}

\author{
Joe S. Matarlo ${ }^{\dagger, \#}$, Yang Lu ${ }^{\dagger, \#}$, Fereidoon Daryaee ${ }^{\dagger}$, Taraneh Daryaee $^{\dagger}$, Bela Ruzsicska ${ }^{\dagger}$, \\ Stephen G. Walker ${ }^{\ddagger}$, and Peter J. Tonge ${ }^{\dagger,}{ }^{*}$ \\ †Institute of Chemical Biology \& Drug Discovery, Department of Chemistry, Stony Brook \\ University, Stony Brook, NY, 11794-3400 \\ \#Institute of Chemical Biology \& Drug Discovery, Department of Oral Biology and Pathology, \\ Stony Brook University, Stony Brook, NY, 11794-3400
}

\begin{abstract}
4-Oxo-4-phenyl-but-2-enoates inhibit MenB, the 1,4-dihydroxyl-2-naphthoyl-CoA synthase in the bacterial menaquinone (MK) biosynthesis pathway, through the formation of an adduct with coenzyme A (CoA). Here, we show that the corresponding methyl butenoates have MIC values as low as $0.35-0.75 \mu \mathrm{g} / \mathrm{mL}$ against drug sensitive and resistant strains of Staphylococcus aureus. Mode of action studies on the most potent compound, methyl 4-(4-chlorophenyl)-4-oxobut-2enoate (1), reveal that $\mathbf{1}$ is converted into the corresponding CoA adduct in $S$. aureus cells, and that this adduct binds to the $S$. aureus MenB ( $s a \mathrm{MenB}$ ) with a $K_{d}$ value of $2 \mu \mathrm{M}$. The antibacterial spectrum of $\mathbf{1}$ is limited to bacteria that utilize MK for respiration, and the activity of $\mathbf{1}$ can be complemented with exogenous MK or menadione. Finally, treatment of methicillin-resistant $S$. aureus (MRSA) with $\mathbf{1}$ results in the small colony variant phenotype and thus $\mathbf{1}$ phenocopies knockout of the $m e n B$ gene. Taken together the data indicate that the antibacterial activity of $\mathbf{1}$ results from a specific effect on MK biosynthesis. We also evaluated the in vivo efficacy of $\mathbf{1}$ using two mouse models of MRSA infection. Notably, compound $\mathbf{1}$ increased survival in a systemic infection model and resulted in a dose-dependent decrease in bacterial load in a thigh infection model, validating MenB as a target for the development of new anti-MRSA candidates.
\end{abstract}

\section{Keywords}

Menaquinone biosynthesis; Staphylococcus aureus; MenB; electrophilic antibacterial compound; DHNA; menadione

\footnotetext{
*Corresponding author ; Email: peter.tonge@ stonybrook.edu, telephone: (631) 632-7907

\#These authors contributed equally to this work.

ASSOCIATED CONTENTS

Supporting Information is available free of charge in the ACS Publication website at DOI: 1) Comparison of theoretical vs observed ion isotopic distribution of $\mathbf{8 , 2}$ ) Thermodynamic constants for the binding of CoA and CoA adducts $\mathbf{7}$ and $\mathbf{8}$ to saMenB, 3) Role of Menaquinone (MK) in the Electron Transport Chain, 4) 4-Oxo-4-phenylbutanoic acids are able to mimic the transition state of the MenB reaction by forming CoA adducts through a Michael addition reaction, 5) Menaquinone quantification in MRSA treated with $1 / 2$ MIC of anti-bacterial agents, 6) Isothermal titration calorimetry (ITC) binding thermographs, 7) High Resolution LC/UV/MS ESI ${ }^{-}$of OSB-CoA, 8) LC/ESI ${ }^{+}$chromatograms for DHNA standard, 9) NMR and MS of compound 8.
} 


\section{Introduction}

There is an urgent need to identify new drug targets to combat the rising threat of antibiotic resistant bacteria including methicillin-resistant Staphylococcus aureus (MRSA), which the Center for Disease Control and Prevention (CDC) ranks as one of the top 10 "serious threats" in the United States. ${ }^{1-4} S$. aureus infection is the leading cause of nosocomial dermatitis, folliculitis, osteomyelitis, endocarditis and bacteremia worldwide, ${ }^{5}{ }^{9}$ and the cost of treating these infections is currently $\$ 20$ billion per year. ${ }^{10}, 11$ Vancomycin is the drug of last resort for treating MRSA infection, but the advent of vancomycin-resistant strains of $S$. aureus in clinical settings, ${ }^{12}, 13$ mitigates the development of new chemotherapeutics to treat these highly dangerous strains.

One major hurdle to treating $S$. aureus infection is the ability of this organism to persist in a slow growth small colony variant (SCV) phenotype. Although many bacteria are known to form SCVs as a natural survival mechanism, ${ }^{14 \_17}$ S. aureus SCVs hamper rapid clinical diagnosis and complicate routine laboratory tests, often leading to misidentification and ultimately misdiagnosis. Furthermore, due to the slow growth characteristics of $S$. aureus SCVs, clinical studies have shown that they are highly drug resistant, less prone to eliciting strong immune responses, and are a source of persistent infection. ${ }^{18}{ }^{22}$ Thus, it is important to treat $S$. aureus infection with therapeutic agents at drug concentrations where SCVs are not induced, ${ }^{23}$ and to develop antimicrobial agents that act specifically on SCVs. The SCV phenotype can arise from genetic and metabolic defects, ${ }^{24} 26$ environmental pressure, ${ }^{27}, 28$ and metabolite auxotrophism. ${ }^{25}, 29,30$ Three well defined SCV auxotrophisms have been identified in which wild-type growth can be restored by supplementation with thymidine, ${ }^{31}$ $\mathrm{CO}_{2},{ }^{27}, 32$ and molecules that complement deficiencies in electron-transport. ${ }^{33}{ }^{35}$ Typically, for electron-transport deficient SCVs, the wild-type phenotype can be restored by supplementation with menaquinone (MK, Vitamin K2) or menadione (MD, Vitamin $\mathrm{K} 3){ }^{34},{ }^{36}$ In some cases, this auxotrophism has been directly linked to mutations in enzymes that constitute the MK biosynthesis pathway. ${ }^{34}, 36,37$

S. aureus and other Gram-positive bacteria utilize MK during oxidative and fermentative respiration as an electron carrier in the electron transport chain (Figure S1). ${ }^{38}, 39$ The classical de novo MK biosynthesis pathway consists of at least nine distinct enzymes (Scheme 1), and is absent in humans, making MK biosynthesis an attractive therapeutic target. Enzymes in this pathway have been implicated in the survival and virulence of many human pathogens, and several classes of inhibitors have been developed to interrogate the pathway as a prelude to novel antibacterial discovery. ${ }^{40} 44$ In our own studies, we have undertaken detailed characterization and inhibition studies of several enzymes in the pathway including MenB, the 1,4-dihydroxynaphthol-CoA synthase. Mutations in MenB have been shown to correlate with $S$. aureus strains that are auxotrophic for menadione, ${ }^{36}$ and genetic approaches have demonstrated that MenB is essential for growth of Mycobacterium tuberculosis. ${ }^{45}$

MenB is the sixth enzyme in the MK pathway and catalyzes an intramolecular Claisen condensation (Dieckmann) reaction leading to the formation of 1,4-dihydroxynaphthoylCoA (DHNA-CoA). ${ }^{46}$ We previously conducted a high throughput screen on MenB from $M$. 
tuberculosis ( $m t \mathrm{MenB}$ ) and identified several classes of $m t \mathrm{MenB}$ inhibitors including the 4oxo-4-phenyl-2-amino butanoates. ${ }^{41}$ We subsequently demonstrated that elimination of the 2-amino substituent occurs in aqueous solution to generate the corresponding butenoate which reacts with CoA to form an adduct that inhibits MenB (Figure S2). ${ }^{46} 49$ We also reported that while the butanoate CoA adducts were potent $m t \mathrm{MenB}$ inhibitors in vitro $\left(K_{i}\right.$ $50 \mathrm{nM}$ ), the corresponding butenoic acids were poor bacterial growth inhibitors (MIC 25 $\mu \mathrm{g} / \mathrm{mL}$ against $\mathrm{H} 37 \mathrm{Rv})$. In contrast, the corresponding methyl butenoates were found to have promising MICs (MIC $<1 \mu \mathrm{g} / \mathrm{mL} \mathrm{H} 37 \mathrm{Rv}$ ), suggesting that protection of the carboxylate aids cell penetration. We now extend these studies to probe their mode of action in $S$. aureus. We first demonstrate that the methyl 4-oxo-4-phenyl-2-butenoates are active against both drug sensitive $S$. aureus (MSSA) and MRSA in vitro, and that their spectrum of activity extends to other bacteria that synthesize MK. We subsequently show that treatment of MRSA cells with the most potent methyl butenoate (1) leads to formation of the corresponding CoA adduct, and results in the SCV growth phenotype, thus phenocopying knockout of the menB gene. In addition, we demonstrate that compound $\mathbf{1}$ reduces levels of both MK as well as DHNA, a downstream product of MenB, and that the antibacterial activity of $\mathbf{1}$ can be rescued by supplementing with exogenous MK, supporting the proposed mode of action. Finally, we find that the most potent methyl ester conjugate is active against MRSA in mouse models where it can prolong survival time and reduces bacterial load.

\section{Results and Discussion}

\section{Methyl 4-oxo-4-(4-chlorophenyl)-2-butenoate (1) has potent activity against S. aureus}

Previously we identified a series of 4-oxo-4-phenyl-2-butenoate inhibitors of the MenB from M. tuberculosis and demonstrated that the corresponding methyl esters had potent antibacterial activity against replicating and non-replicating $M$. tuberculosis $(0.6-1.5 \mu \mathrm{g} /$ $\mathrm{ml}){ }^{41}$ To explore the activity and mode of action of these compounds in $S$. aureus, we first evaluated the whole cell antibacterial activity of several methyl butenoates against methicillin sensitive and resistant $S$. aureus (MSSA and MRSA, respectively). The minimum inhibitory concentrations (MIC) are summarized in Table 1 where it can be seen that the 4chloro analog 1 has the most promising antibacterial activity with MIC values of 0.35 and $0.75 \mu \mathrm{g} / \mathrm{mL}$ against MSSA and MRSA, respectively. We subsequently focused our efforts on interrogating the mode of action of $\mathbf{1}$ in $S$. aureus.

\section{1 is a Specific Inhibitor for MK Utilizing Bacteria}

Bacteria generally utilize structural analogs of either ubiquinone (Q) or MK as the lipid soluble redox active electron carrier in the electron transport chain. To explore the spectrum of antibacterial activity, we thus selected bacteria that use either Q or MK for respiration. The Gram-positive bacteria Bacillus subtilis and Enterococcus faecium, as well as Mycobacterium smegmatis and the Gram-negative bacterium Haemophilus influenza, use MK when grown either aerobically or anaerobically. Conversely, Pseudomonas aeruginosa uses Q under all growth conditions whereas the Gram-negative bacteria Escherichia coli, Klebsiella pneumoniae, and Proteus mirabilis use $\mathrm{Q}$ under aerobic growth conditions but switch to MK when grown anaerobically (Table 2). Antibacterial assays revealed that $\mathbf{1}$ was only active under growth conditions where MK was the primary electron carrier. Thus, $\mathbf{1}$ was 
active against $B$. subtilis, E. faecium and $M$. smegmatis, under aerobic, capnophilic, and anaerobic growth conditions, consistent with our previous work where $\mathbf{1}$ demonstrated MIC values of 0.64 and $1.5 \mu \mathrm{g} / \mathrm{mL}$ against $M$. tuberculosis grown aerobically or in the low oxygen recovery assay, respectively. ${ }^{41}$ In addition, whereas compound $\mathbf{1}$ showed no activity towards E. coli, $P$. mirabilis and $K$. pneumoniae under aerobic growth conditions, MIC values of $12.5 \mu \mathrm{g} / \mathrm{mL}$ (E. coli and P. mirabilis) and $62.5 \mu \mathrm{g} / \mathrm{mL}$ (K. pneumoniae) were observed under anaerobic conditions. Compound $\mathbf{1}$ also demonstrated activity towards $H$. influenza grown under capnophilic conditions (MIC $0.25 \mu \mathrm{g} / \mathrm{mL}$ ) but showed no activity towards $P$. aeruginosa under either aerobic, capnophilic, or anaerobic conditions.

Complementation studies were performed by supplementing the media with $10 \mu \mathrm{M}$ MK-4 or $\mathrm{MD}$, and in organisms for which $\mathbf{1}$ displayed an MIC, addition of MK-4 resulted in an increase in the MIC value to $>60 \mu \mathrm{g} / \mathrm{mL}$.

Although these studies provide strong support that the antibacterial activity of $\mathbf{1}$ results from a direct effect on MK biosynthesis, we speculated that if $\mathbf{1}$ did have additional target(s) unrelated to MK biosynthesis, then the lack of activity of $\mathbf{1}$ against the Gram-negative bacteria that were grown aerobically (i.e. where they utilize $\mathrm{Q}$ and not MK) might be due to an inability of the compound to penetrate the bacteria. Thus, we evaluated the activity of $\mathbf{1}$ against $P$. aeruginosa, $K$. pneumoniae, and $P$. mirabilis under aerobic conditions in the presence of $1 / 2$ MIC polymyxin B to improve cell permeability. ${ }^{50}, 51$ However, this did not alter the whole cell activity of $\mathbf{1}$, suggesting that the lack of activity was not caused by uptake issues.

\section{Reduces MK level in MRSA}

$S$. aureus produces an array of MK species that differ in the length of the isoprenyl chain attached to the naphthoquinone nucleus. In agreement with previous studies, MK-8 (8 isoprenyl units) was found to be the most abundant MK in $S$. aureus (Figure S3). ${ }^{24}, 38,52,53$ In order to analyze the impact of $\mathbf{1}$ on MK levels in growing cells, the change in MK-8 by treatment of MRSA with $\mathbf{1}$ was quantified by tandem mass spectrometry using commercially available MK-9 as a standard (Figure 1). Treatment of MRSA cells with increasing concentrations of $\mathbf{1}(1 / 10,1 / 5,1 / 3$, and $1 / 2$ MIC) resulted in a dose dependent decrease in MK-8 (Figure 1A). In addition, whereas $1 / 2$ MIC of $1(0.375 \mu \mathrm{g} / \mathrm{mL})$ reduced the relative amount of MK- 8 by $75 \%, 1 / 2$ MIC of vancomycin $(2 \mu \mathrm{g} / \mathrm{mL})$ only resulted in a $\sim 10 \%$ change, again consistent with a specific effect of $\mathbf{1}$ on MK biosynthesis (Figure 1B).

\section{Forms a CoA Adduct in MRSA Treated Cells}

Previously, we reported that the 4-oxo-4-phenyl-2-butenoates form a CoA adduct in vitro which is responsible for the inhibition of MenB. ${ }^{41}$ We thus speculated that the antibacterial activity of $\mathbf{1}$ results from the formation of this CoA adduct (8) (Table 3) in cells where it may inhibit MenB. Using high resolution LC/UV/MS we could demonstrate the accumulation of $\mathbf{8}$ (calculated $\mathrm{m} / z=991.1392$ ) in treated cells with peaks corresponding to $[\mathrm{M}-\mathrm{H}]^{-}=990.1315$ and $[\mathrm{M}-2 \mathrm{H}]^{2-}=494.5608$ (Figure 2). Isotopic distribution peaks corresponding to the $2 \mathrm{~m} / \mathrm{z}$ increase due to the presence of $\mathrm{Cl}$ in the molecule were also observed: $[\mathrm{M}-\mathrm{H}]^{-}=990.1315\left({ }^{35} \mathrm{Cl}\right) \& 992.1300\left({ }^{37} \mathrm{Cl}\right)$ (Figure 2 inset, Table S1), thus clearly indicating the formation of $\mathbf{8}$ from treatment of $\mathbf{1}$ in MRSA cells. 


\section{Inhibition of saMenB by 8}

Although the presence of $\mathbf{8}$ in MRSA treated cells was not unsurprising, we initially hypothesized that the active species would be the acid form $\mathbf{7}$ since this is a potent inhibitor of $m t M e n B$ (Figure S2). This hypothesis stemmed from the knowledge that esterification is used as a strategy to protect free-carboxylates to facilitate cell penetration after which hydrolysis by endogenous esterases liberates the active pharmacophore. ${ }^{54}, 55$ However, using high resolution LC/UV/MS, we were unable to detect 7 in cell extracts (Figure 2). We thus explored the ability of $\mathbf{8}$ and the corresponding acid (7) to bind to and inhibit saMenB in vitro. Using the MenE-MenB coupled assay, ${ }^{56}$ we discovered that both $\mathbf{7}$ and $\mathbf{8}$ inhibit saMenB with similar $I C_{50}$ values $(4-7 \mu \mathrm{M}$, Table 3$)$. In addition we also used ITC to quantify binding of $\mathbf{7}$ and $\mathbf{8}$ to saMenB. The data shown in Figure S4 were fit to a one-site binding model yielding $K_{\mathrm{d}}$ values of $2.8 \mu \mathrm{M}$ for each ligand (Table 3). In comparison, CoA has a $K_{\mathrm{d}}$ value of $25 \mu \mathrm{M}$ for $s a \mathrm{MenB}$ showing that the acyl group provides an additional 1.3 $\mathrm{kcal} / \mathrm{mol}$ in binding energy equivalent to the formation of one hydrogen bond between the acyl group and the enzyme $(\Delta \Delta G=1.3 \mathrm{kcal} / \mathrm{mol}$ ) (Table S2). Since the inhibition of $s a M e n B$ was assessed using a coupled assay which involved generation of the MenB substrate using MenE, we also verified that $\mathbf{7}$ and $\mathbf{8}$ did not bind to nor inhibit MenE (Table 3).

\section{Reduces the Level of DHNA in MRSA Cells}

To further probe if $\mathbf{1}$ directly targets saMenB in MRSA, we posited that the substrate of MenB, OSB-CoA, would accumulate in treated cells. The mass spectrum of OSB-CoA has peaks at $[\mathrm{M}-\mathrm{H}]^{-}=970.1492$ and $[\mathrm{M}-2 \mathrm{H}]^{2-}=484.5686$ (Figure S5). However, using this as a standard, we were not able to detect OSB-CoA in extracts from untreated cells or those treated with $\mathbf{1}$. We posited that our inability to detect OSB-CoA might be related to the relative instability of this metabolite which can undergo a non-enzymatic rearrangement leading to the formation of spirodilactone (Scheme 1). However, we were also unable to detect spirodilactone in either treated or untreated cells. We then searched for the downstream product of MenB and determined that levels of DHNA were substantially reduced in MRSA cells treated with 1 (Figure 3). Commercially available DHNA was used as a standard for method development and MS detection. The retention time of DHNA was determined to be $12.22 \mathrm{~min}$ with a $[\mathrm{M}+\mathrm{H}]^{+}$of 205.0499. DHNA undergoes facile MS fragmentation with the loss of $\mathrm{CO}_{2}$ to give a $\mathrm{m} / z=159.0443$ ion, and also yields ions with $\mathrm{m} / z=227.0321\left([\mathrm{M}+\mathrm{Na}]^{+}\right), \mathrm{m} / z=131.0493$ (loss of CO) and 103.0546 (loss of CO) (Figure S6). Extracts from untreated cells were shown to contain DHNA (retention time $12.26 \mathrm{~min}$ ) (Figure 3A) characterized by ESI ${ }^{+}$peaks at $\mathrm{m} / \mathrm{z}=205.0499\left([\mathrm{M}+\mathrm{H}]^{+}\right), 159.0439,131.049$ and 103.055 (Figure 3B). However, DHNA could not be detected in cells treated with 1 (Figure 3C), supporting a specific effect of $\mathbf{1}$ on saMenB.

\section{MRSA Treated with 1 Forms SCVs and Phenocopies Genetic Disruption of menB}

Previous reports have shown that genetic defects in the $m e n B$ gene as well as knockout/ knockdown of MenB result in the SCV phenotype, and that supplementation with exogenous MK-4 or MD can restore the wild-type phenotype. ${ }^{24}, 36$ We thus investigated the morphology of MRSA colonies grown on tryptic soy agar (TSA) plates in the presence or absence of 1 (Figure 4). The agar MIC of 1 was found to be $8 \mu \mathrm{g} / \mathrm{mL}$, which was higher than 
the broth MIC, a difference often observed for antibacterial compounds. ${ }^{57}$ Growth of MRSA on TSA containing $4 \mu \mathrm{g} / \mathrm{mL}$ of $\mathbf{1}(1 / 2$ agar MIC) showed no colonies after $24 \mathrm{hr}$, in contrast to cells grown in the absence of $\mathbf{1}$, while small colonies appeared in the presence of $\mathbf{1}$ after 48 $\mathrm{hr}$, consistent with the SCV phenotype. Addition of $10 \mu \mathrm{M}$ MK-4 to the TSA plates together with $16 \mu \mathrm{g} / \mathrm{mL} 1$ (2x agar-MIC) showed wild-type growth, indicating that MK-4 can abrogate the antibacterial activity of $\mathbf{1}$. Figure 4 also contains data on the growth of a men $B^{-1-}$ strain, ${ }^{24}$ showing formation of small, pigmentless, slow-growing colonies after 48 $\mathrm{hr}$. Thus, treatment of MRSA with sub-MIC concentrations of $\mathbf{1}$ phenocopies disruption of the $m e n B$ gene.

Complementation of defects in MK biosynthesis by MK-4 or MD has been hypothesized to occur either by directly replacing MK in the electron transport chain or by acting as substrates for the de novo synthesis of MK. To explore these possibilities, we analyzed the MK distribution in MRSA cells treated with $\mathbf{1}$ and supplemented with either MK-4 or MD (Figure 5). Although MK-4 supplementation did not lead to recovery of the natural MK distribution, addition of MD to the media resulted in a distribution of MK species that closely resembled that observed in the absence of 1 (Figure 5). Thus for the first time, we can conclude that MD can be used as a precursor for the synthesis of MK by enzyme(s) that are downstream of MenB, possibly as a substrate for MenA which adds the isoprenyl side chain to the naphthoquinone ring. MK-4 in contrast can be directly used in oxidative respiration.

\section{Shows Promising Antibacterial Activity Against MRSA in Vivo}

We evaluated the antibacterial activity of $\mathbf{1}$ in both systemic and thigh MRSA infection mouse models (Figure 6). Oxacillin served as a negative control for both models since this drug does not have antibacterial activity against MRSA in vitro, whereas vancomycin was used as a positive control (Table 1). In the systemic infection group, control animals which received only vehicle or oxacillin died within two days post-infection with an average survival rate of 1.5-1.6 days. In contrast, vancomycin increased the survival rate up to 5.8 days post infection. Promisingly, treatment with $100 \mathrm{mg} / \mathrm{kg}$ of 1 resulted in a survival rate of 4.6 days $(p<0.005)$ (Figure 6A). In addition, increasing concentrations of 1 resulted in a dose dependent reduction in bacterial burden in the thigh model of infection, with 100 $\mathrm{mg} / \mathrm{kg}$ reducing bacterial load by $3.1 \log$ CFU/gram tissue (Figure 6B). This contrasted with only a minimal effect of oxacillin on bacterial load, whereas vancomycin caused a reduction of $4.2 \log$ CFU/gram of tissue. Thus, $\mathbf{1}$ demonstrates promising in vivo efficacy using both systemic and thigh models of MRSA infection.

\section{Outlook and Conclusions}

Previously we performed an HTS to identify inhibitors of MenB, the 1,4dihydroxynaphthoyl-CoA synthetase in the bacterial MK pathway. This HTS yielded several classes of inhibitors including a series of 2-amino-4-oxo-4-phenylbutanoates. We subsequently demonstrated that the 2-aminobutanoates eliminate the amino group, yielding the corresponding butenoate which then reacts with CoA to form an adduct that inhibits MenB. Although the butenoic acids have poor antibacterial activity, the methyl ester derivatives have potent activity, suggesting that the lack of activity of the butenoic acids 
results from poor penetration into the cell. In the present work, we have expanded our studies to explore the mode of action of the methyl butenoates in $S$. aureus. Methyl 4-oxo-4(4-chlorophenyl)-2-butenoate $\mathbf{1}$ has potent activity against the human pathogen $M$. tuberculosis (MIC $0.64 \mu \mathrm{g} / \mathrm{mL}$ ). Here, we show that 1 also has potent antibacterial activity against MSSA and MRSA, as well as other MK-utilizing bacteria. We also provide compelling evidence that the activity of $\mathbf{1}$ results from a direct effect on MK biosynthesis through inhibition of saMenB (Figure 7). We show that $\mathbf{1}$ can penetrate into MRSA cells and form a CoA adduct that is an inhibitor of $s a \mathrm{MenB}$. Treatment with $\mathbf{1}$ depletes DHNA levels, reduces MK, and ultimately results in the formation of the SCV growth phenotype, thus phenocopying a men $B^{-/-}$knockout strain. ${ }^{24}$ The growth defects caused by $\mathbf{1}$ can be recovered by addition of MK-4 or MD to the media, and we demonstrate that complementation with MD results from conversion of this compound into MK. Finally, given the potent in vitro activity of $\mathbf{1}$, we evaluated the in vivo efficacy of this compound in two mouse models of MRSA infection and show that $\mathbf{1}$ increases survival time and reduces bacterial load. These studies thus validate the MK biosynthesis pathway as a target for the development of novel antibacterial agents.

Whilst 1 is a useful chemical tool for exploring the role of MenB and MK biosynthesis in bacterial growth and survival, it is likely that $\mathbf{1}$ also reacts with other nucleophiles in the cell. Improvements in the selectivity of compounds derived from $\mathbf{1}$ can be envisaged based on elegant approaches that have been applied to the generation of selective covalent kinase inhibitors including compounds that target Bruton's tyrosine kinase (BTK) ${ }^{58}$ such as ibrutinib, ${ }^{59}$ and CC-292, ${ }^{60}$ as well as the reversible covalent cyanoacrylamides developed by Taunton and co-workers. ${ }^{61}, 62$ In this regard, the observation that CoA can bind to MenB suggests that modifications that reduce the electrophilicity of the Michael acceptor whilst increasing the affinity of $\mathbf{1}$ for the enzyme might lead to compounds that inhibit MenB through the formation of the CoA adduct on the enzyme. In addition, it is known that variation in the substitution of the phenyl ring in the 4-oxo-4-phenyl-2-amino butanoates alters the rate at which the amine is eliminated from these compounds, ${ }^{41}$ and such changes are also envisaged to alter the stability of the corresponding thiol adducts. Thus, the reversible covalent formation of CoA adducts that are stabilized by MenB might also provide a strategy for improving the selectivity of molecules that target MenB.

\section{Materials and Methods}

\section{Compounds}

Chemicals were obtained from commercial vendors and used without further purification. The compounds tested for activity were available from previous studies. ${ }^{41}$ The CoA adduct of methyl 4-oxo-4-(4-chlorophenyl)-2-butenoate (8) was prepared as follows: a solution of CoA $(0.1 \mathrm{mmol})$ in water $(1.5 \mathrm{~mL})$ was added to a solution of methyl 4-oxo-4-(4chlorophenyl)-2-butenoate $(0.5 \mathrm{mmol})$ in anhydrous DMSO $(1 \mathrm{~mL})$ at RT. The resulting mixture was stirred at RT for $4 \mathrm{hr}$ after which the reaction was quenched by addition of formic acid $(0.1 \%, 0.5 \mathrm{~mL})$. The product was purified by HPLC using a Shimadzu 20AB

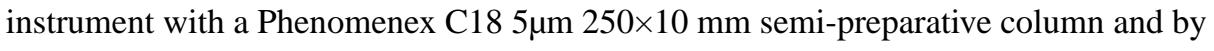
running a gradient of 0 to $40 \%$ acetonitrile in water over $40 \mathrm{~min}$ at a flow rate of $4 \mathrm{~mL}$. The 
product eluted at $15 \mathrm{~min}$ and was obtained by lyophilization. $\mathrm{ESI}^{-}$calculated for $[\mathrm{M}-\mathrm{H}]^{-}$ $\mathrm{C}_{32} \mathrm{H}_{45} \mathrm{ClN}_{7} \mathrm{O}_{19} \mathrm{P}_{3} \mathrm{~S}$ (compound 8) 990.13, found 990.2 (Figure S7).

\section{S. aureus MenB (saMenB)}

The gene encoding MenB was cloned from MRSA (Rosenbach, ATCC BAA-1762) into a pET28a ${ }^{+}$plasmid so that a $6 \mathrm{x}-\mathrm{HIS}$ tag was encoded at the N-terminus. The expression and purification of $s a \mathrm{MenB}$ followed a similar method to that described previously for $E$. coli MenB. ${ }^{46}$ Briefly, protein expression was induced with $0.5 \mathrm{mM}$ IPTG when the $\mathrm{OD}_{600}$ of the culture reached 0.55 , after which the culture was shaken overnight at $22{ }^{\circ} \mathrm{C}$. Cells were collected by centrifugation, re-suspended in $20 \mathrm{mM}$ sodium phosphate buffer $\mathrm{pH} 8.5$ containing $250 \mathrm{mM} \mathrm{NaCl}, 1 \mathrm{mM} \mathrm{MgCl}$ and protease inhibitor cocktail, and then lysed by passing the suspension twice through a cell disruptor (35 kpsi). Following ultracentrifugation, $s a \mathrm{MenB}$ was purified from the supernatant by affinity chromatography with HIS bind resin and by running an imidazole gradient from 20-500 mM. Fractions containing saMenB were pooled and chromatographed on a Sephadex 75 column using 20 $\mathrm{mM}$ sodium phosphate buffer $\mathrm{pH} 8.5$ containing $250 \mathrm{mM} \mathrm{NaCl}$ and $1 \mathrm{mM} \mathrm{MgCl}_{2}$ as the eluent to rapidly remove imidazole. The protein was concentrated to $\sim 40 \mu \mathrm{M}\left(\varepsilon_{280}=33,140\right.$ $\mathrm{M}^{-1} \mathrm{~cm}^{-1}$ ) and stored at $-80^{\circ} \mathrm{C}$.

\section{Kinetic Assays}

Enzyme inhibition studies were performed in $20 \mathrm{mM}$ sodium phosphate buffer $\mathrm{pH} 8.5$ containing $250 \mathrm{mM} \mathrm{NaCl}$ and $1 \mathrm{mM} \mathrm{MgCl}_{2}$ using a MenE-MenB coupled assay in which saMenB was rate-limiting. ${ }^{47} I C_{50}$ values were determined in reaction mixtures containing osuccinylbenzoate $(60 \mu \mathrm{M})$, ATP $(120 \mu \mathrm{M})$, CoA $(120 \mu \mathrm{M})$, saMenB $(0.1 \mu \mathrm{M})$, and varying inhibitor concentrations $(0.05-250 \mu \mathrm{M})$. Reactions were initiated by addition of ecMenE ( 5 $\mu \mathrm{M}$ ) with or without $1 \mathrm{hr}$ incubation in $37^{\circ} \mathrm{C}$ and the production of DHNA-CoA was monitored at $392 \mathrm{~nm}\left(\varepsilon_{392}=4,000 \mathrm{M}^{-1} \mathrm{~cm}^{-1}\right)$.

\section{Isothermal Titration Calorimetry (ITC)}

ITC was used to quantify the affinity of CoA and the CoA adducts $\mathbf{7}$ and $\mathbf{8}$ for $s a \mathrm{MenB}$ using a Micro-Cal VP-ITC instrument. Aliquots of $2 \mathrm{mM}$ ligand ( 4 or $8 \mu \mathrm{L})$ were titrated into a solution of $25 \mu \mathrm{M} s \mathrm{sanB}(1.8 \mathrm{~mL})$ using a 12-20 s titration period with $300 \mathrm{~s}$ between each titration. Lyophilized ligands were dissolved in the same buffer as that used for the enzyme (20 mM sodium phosphate buffer $\mathrm{pH} 8.5$ containing $250 \mathrm{mM} \mathrm{NaCl}$ and $1 \mathrm{mM}$ $\mathrm{MgCl}_{2}$ ). ITC experiments were performed at $22{ }^{\circ} \mathrm{C}$.

\section{Bacterial Strains and Antibacterial Assays}

Bacterial strains used in this study included methicillin-sensitive (MSSA, ATCC 25923), and -resistant (MRSA, BAA 1762) S. aureus, E. coli (ATCC 25922), Bacillus subtilis (ATCC 6051), Haemophilus influenzae (ATCC 49427), Enterococcus faecium (ATCC 19434), Klebsiella pneumoniae (ATCC 13883), Proteus mirabilis (ATCC 35659), Pseudomonas aeruginosa (ATCC 27853), and Mycobacterium smegmatis (ATCC 700084). Minimum inhibitory concentrations (MICs) were determined using visual inspection of cells grown in transparent 96 -well plates. Bacteria were grown to mid-log phase $\left(\mathrm{OD}_{600}\right.$ of $\left.0.6-0.8\right)$ in 
Mueller Hinton broth, tryptic soy broth, or $7 \mathrm{H} 9$ media at $37{ }^{\circ} \mathrm{C}$ in an orbital shaker. A final inoculum concentration of $10^{6} \mathrm{CFU} / \mathrm{mL}$ per well was treated with inhibitor in a 2-fold dilution series at concentrations ranging from $0.06-125 \mu \mathrm{g} / \mathrm{mL}$. MIC values under capnophilic conditions were obtained in a humidified candle jar and using a candle to obtain $\left(\sim 8 \% \mathrm{O}_{2}\right)$. GasPak EZ Anaerobe Sachets (BD 260001) were used to obtain anaerobic conditions $\left(<0.1 \% \mathrm{O}_{2}\right)$. The MIC was defined as the minimum concentration (modal value) at which no obvious growth was observed after $24-72 \mathrm{hr}$ incubation were used at $37^{\circ} \mathrm{C}$. Complementation studies were performed by supplementing synthetic broth with $10 \mu \mathrm{M}$ menaquinone-4 (MK4) or $10 \mu \mathrm{M}$ menadione (MD).

\section{Quantification of MK Levels}

MK was extracted from $S$. aureus cells using a liquid-liquid extraction method. ${ }^{63}, 64$ A 100 $\mathrm{mL}$ starter culture of MRSA in Mueller Hinton-II (MH-II) broth was treated with $1 / 2$ MIC of vancomycin $(2 \mu \mathrm{g} / \mathrm{mL})$ or $\mathbf{1}(0.38 \mu \mathrm{g} / \mathrm{mL})$. Cultures were incubated at $37{ }^{\circ} \mathrm{C}$ in an orbital shaker to late-log phase $\left(\mathrm{OD}_{600}\right.$ between 0.9 and 1.0) and then diluted with $\mathrm{MH}-\mathrm{II}$ broth to $10^{9}$ cells $/ \mathrm{mL}$. Cells were isolated from $100 \mathrm{~mL}$ of culture by centrifugation $(5,000 \mathrm{rpm}, 30$ minutes) and then re-suspended in $30 \mathrm{~mL}$ phosphate buffer $\left(50 \mathrm{mM} \mathrm{KH}_{2} \mathrm{PO}_{4}, \mathrm{pH}\right.$ 7.0). The suspension was extracted with 20:15 mL methanol:chloroform. The lower organic layer was collected, washed with brine $(30 \mathrm{~mL})$ and dried with $\mathrm{MgSO}_{4}$ prior to MS/MS analysis. MK quantification was conducted using a flow injection analysis (FIA)-atmospheric-pressure chemical ionization (APCI)-MS/MS system and TSQ Quantum Access triple Quadruple mass spectrometer. Briefly, $5 \mu \mathrm{L}$ of sample was loop injected and the flow was directed to the APCI source. Mass spectrometry was performed in positive ion mode with $3.5 \mathrm{kV}$, gas pressure $30 \mathrm{psi}$, and a capillary temperature $350{ }^{\circ} \mathrm{C}$. Multiple Reaction Monitoring (MRM). ${ }^{65}, 66$ transitions were detected at $100 \mathrm{~ms}$ dwell times. Multiple injections were performed over a 5 min time frame. MK-9 was used as a standard for generating a calibration curve. Complementation studies were performed by supplementing synthetic broth with $10 \mu \mathrm{M}$ menaquinone-4 (MK4) or $10 \mu \mathrm{M}$ menadione (MD).

\section{Sample Analyses by LC/UV/MS}

DHNA - High resolution LC/UV/MS analysis was performed on samples prepared as follows. ${ }^{67}, 68$ MRSA was grown to an $\mathrm{OD}_{600}$ of 1 after which $1 \mathrm{~mL}$ of the culture was filtered using a sterile Millipore filter to capture the cells. The filter was transferred to MH-II agar plates where the cells were cultured with or without $8 \mu \mathrm{g} / \mathrm{mL}$ of $\mathbf{1}$ for $18 \mathrm{hr}$. Cells were harvested from the filter, lysed by bead-beating and centrifuged in a SpinX column. Samples of the supernatant were analyzed by high resolution LC/UV/MS (ESI $\left.{ }^{+}, \mathrm{m} / \mathrm{z}=100-3200\right)$ using an Agilent LC-UV-TOF mass spectrometer (G6224A oaTOF). The LC was performed using a Kinetex XB-C18 column $(100 \AA$, $2.6 \mu \mathrm{m}, 150 \times 2.1 \mathrm{~mm})$ with $0.1 \% \mathrm{HOAc} / \mathrm{H}_{2} \mathrm{O}$ (solvent A) and $\mathrm{CH}_{3} \mathrm{OH}$ (solvent $\mathrm{B}$ ) at $45^{\circ} \mathrm{C}$. The flow rate was $0.40 \mathrm{~mL} / \mathrm{min}$ and the amount of solvent B was: 0-2 min 5\% B, 2-32 min 5-95\% B, 32-35 min 95-96\% B. Sample volumes were $5 \mu \mathrm{L}$ for the synthetic standards and $20 \mu \mathrm{L}$ for the sample supernatants.

CoA-derivatives-High resolution LC/UV/MS analysis was performed on samples prepared as described above. The supernatant was centrifuged using a SpinX column and the 
filtrate was lyophilized. Samples were analyzed by high resolution LC/UV/MS (ESI ${ }^{-}, \mathrm{m} /$ $\mathrm{z}=100-3200$ ) using an Agilent LC-UV-TOF mass spectrometer (G6224A oaTOF). The LC was performed using a Kinetex HILIC column $(100 \AA$, $2.6 \mu \mathrm{m}, 150 \times 2.1 \mathrm{~mm})$ with $\mathrm{H}_{2} \mathrm{O}: \mathrm{CH}_{3} \mathrm{CN}$ 1:1 (10mM AmAc, 0.02\% Ac) (solvent A) and $\mathrm{CH}_{3} \mathrm{CN}: \mathrm{H}_{2} \mathrm{O}, 95: 5(10 \mathrm{mM}$ AmAc, $0.02 \% \mathrm{Ac}$ ) (solvent B) at $30^{\circ} \mathrm{C}$. The flow rate was $0.50 \mathrm{~mL} / \mathrm{min}$ and the amount of solvent B was: 0-2 min 96\% B, 2-22.5 min 96-0\% B, 32-35 min 0\% B. Sample volumes were $5 \mu \mathrm{L}$ for the synthetic standards and $25 \mu \mathrm{L}$ for the sample supernatants.

\section{Colony Morphology}

The colony morphology was analyzed by plating MRSA cells on tryptic soy agar (TSA) media with or without 1 . A single colony of MRSA was streaked on a $20 \mathrm{~mL}$ TSA plate containing 0,4 , or $8 \mu \mathrm{g} / \mathrm{mL} \mathbf{1}$. For the rescue experiments, TSA plates contained $16 \mu \mathrm{g} / \mathrm{mL} 1$ and $10 \mu \mathrm{M}$ MK-4 or MD. Plates were incubated for up to $84 \mathrm{hr}$ at $37^{\circ} \mathrm{C}$. In addition to the slow growth phenotype, SCV colonies were also non-pigmented (colorless) in contrast to rapidly growing wild-type yellow colonies. ${ }^{69}$

\section{In Vivo Antibacterial Activity of 1}

All animals were maintained in accordance with the American Association for Accreditation of Laboratory Animal Care criteria and was reviewed and approved by SBU IACUC. Experiments were conducted under BSL-2 conditions in the Division of Laboratory Animal Resources at Stony Brook University. AVMA guidelines on euthanasia after the experiments were followed at the end of each experiment. Six week old, male Swiss Webster mice (Taconic) were used. Systemic infection was induced by intraperitoneal (IP) injection of $2 \times 10^{7} \mathrm{CFU}$ MRSA in $200 \mu \mathrm{L}$ of saline. Drug doses, including vancomycin and oxacillin, were prepared in a vehicle consisting of $40 \%$ saline, $40 \%$ ethanol, $20 \%$ PEG-400, and were delivered by subcutaneous injection (SC) at $1 \mathrm{hr}, 12 \mathrm{hr}$ and $24 \mathrm{hr}$ post infection at a dose of $100 \mathrm{mg} / \mathrm{kg}$. Mortality was checked every $12 \mathrm{hr}$ for 7 days. For the thigh infection model, mice were rendered neutropenic by injecting cyclophosphamide (CPA) 4 days (IP, 150 $\mathrm{mg} / \mathrm{kg}$ ) and 1 day (IP, $100 \mathrm{mg} / \mathrm{kg}$ ) before infection. Thigh infections were performed by injecting MRSA cells $\left(10^{6} \mathrm{CFU}\right.$ in $50 \mu \mathrm{L}$ of saline) into the left thigh muscle (intramuscular, IM). All drugs, including vancomycin and oxacillin, were administered by SC injection $1 \mathrm{hr}$ and $12 \mathrm{hr}$ post infection at a dose of $100 \mathrm{mg} / \mathrm{kg}$ (vancomycin and oxacillin) or 100, 50 and $25 \mathrm{mg} / \mathrm{kg}$ (compound 1). Infected thigh muscles were collected, weighed and homogenized in $2 \mathrm{~mL}$ of saline. Serial dilutions of each homogenized sample were plated on Mueller Hinton agar supplemented with 5\% sheep blood. The number of colony-forming units (CFU) was determined following overnight incubation and the bacterial burden was determined. Statistical significance was determined using a one tail T-test.

\section{Supplementary Material}

Refer to Web version on PubMed Central for supplementary material. 


\section{Acknowledgments}

We thank Dr. Robert Rieger from the Proteomics Center at Stony Brook University for assistance with MK quantification and analysis, and Dr. Eric Skaar from Vanderbilt University for his generous gift - the men $B^{-/-} S$. aureus strain.

Funding: This work was supported by NIH grants GM102864 to PJT and GM100477, and by a W. Burghardt Turner Fellowship to JSM.

\section{ABBREVIATIONS}

$\begin{array}{ll}\text { MRSA } & \text { Methicillin-resistant Staphylococcus aureus } \\ \text { MSSA } & \text { Methicillin-sensitive Staphylococcus aureus } \\ \text { MK } & \text { Menaquinone } \\ \text { DHNA } & \text { 1,4-Dihydroxy-2-naphthoic acid } \\ \text { OSB-CoA } & \text { o-Succinylbenzoyl-Coenzyme A } \\ \text { MIC } & \text { Minimum inhibitory concentration } \\ \text { SCV } & \text { small-colony variant } \\ \text { MD } & \text { menadione } \\ \text { TSA/B } & \text { Tryptic Soy Agar/Broth } \\ \text { CFU } & \text { Colony Forming Unit }\end{array}$

\section{References}

1. Li K, Schurig-Briccio LA, Feng X, Upadhyay A, Pujari V, Lechartier B, Fontes FL, Yang H, Rao G, Zhu W, Gulati A, No JH, Cintra G, Bogue S, Liu YL, Molohon K, Orlean P, Mitchell DA, FreitasJunior L, Ren F, Sun H, Jiang T, Li Y, Guo RT, Cole ST, Gennis RB, Crick DC, Oldfield E. Multitarget drug discovery for tuberculosis and other infectious diseases. J Med Chem. 2014; 57:3126-3139. [PubMed: 24568559]

2. Fischbach MA, Walsh CT. Antibiotics for emerging pathogens. Science. 2009; 325:1089-1093. [PubMed: 19713519]

3. West K. Methicillin-resistant Staph aureus. In this era of resistant organisms, it's vitally important for you to comply with the infection-control procedures set forth by the CDC. Emerg Med Serv. 1993; 22:70-71. 78. [PubMed: 10128799]

4. Kessler R. Superbug hideout: finding MRSA in U.S.wastewater treatment plants. Environ Health Perspect. 2012; 120:A437. [PubMed: 23117334]

5. McKenna M. Vaccine development: Man vs MRSA. Nature. 2012; 482:23-25. [PubMed: 22297951]

6. CDC: hospitals "need to do more" to control MRSA. AHRQ report disheartening. Hosp Peer Rev. 2008; 33:5-6. 11. [PubMed: 18402275]

7. Camins BC, Fraser VJ. Reducing the risk of health care-associated infections by complying with CDC hand hygiene guidelines. Jt Comm J Qual Patient Saf. 2005; 31:173-179. [PubMed: 15828601]

8. Rosenberg Goldstein RE, Micallef SA, Gibbs SG, Davis JA, He X, George A, Kleinfelter LM, Schreiber NA, Mukherjee S, Sapkota A, Joseph SW, Sapkota AR. Methicillin-resistant Staphylococcus aureus (MRSA) detected at four U.S. wastewater treatment plants. Environ Health Perspect. 2012; 120:1551-1558. [PubMed: 23124279] 
9. Barrado L, Branas P, Rojo P, Gomez-Gonzalez C, Barrios M, Orellana MA, Chaves F. Molecular epidemiology of Staphylococcus aureus bacteremia in children, Spain: low risk of methicillin resistance. J Infect. 2014; 68:195-198. [PubMed: 24125904]

10. Jones M, Huttner B, Leecaster M, Huttner A, Damal K, Tanner W, Nielson C, Rubin MA, Goetz MB, Madaras-Kelly K, Samore MH. Does universal active MRSA surveillance influence antiMRSA antibiotic use? A retrospective analysis of the treatment of patients admitted with suspicion of infection at Veterans Affairs Medical Centers between 2005 and 2010. J Antimicrob Chemother. 2014; 69:3401-3408. [PubMed: 25103488]

11. Kalenic S, Pal MP, Palcevski VV, Horvatic J, Mestrovic T, Barsic B, Stamenic V, Burcar I, Korusic A, Vucic M, Civljak R, Stancic M, Budimir A. [Guidelines for prevention, control and treatment of infections caused by methicillin-resistant Staphylococcus aureus (MRSA): changes and updates of chapter 7.0: treatment of patients with MRSA infection]. Lijec Vjesn. 2010; 132:340-344. [PubMed: 21294322]

12. Gould IM. VRSA-doomsday superbug or damp squib? Lancet Infect Dis. 2010; 10:816-818. [PubMed: 21109164]

13. Aguado JM, San-Juan R, Lalueza A, Sanz F, Rodriguez-Otero J, Gomez-Gonzalez C, Chaves F. High vancomycin MIC and complicated methicillin-susceptible Staphylococcus aureus bacteremia. Emerg Infect Dis. 2011; 17:1099-1102. [PubMed: 21749780]

14. Malone JG. Role of small colony variants in persistence of Pseudomonas aeruginosa infections in cystic fibrosis lungs. Infect Drug Resist. 2015; 8:237-247. [PubMed: 26251621]

15. Haussler S, Rohde M, Steinmetz I. Highly resistant Burkholderia pseudomallei small colony variants isolated in vitro and in experimental melioidosis. Med Microbiol Immunol. 1999; 188:9197. [PubMed: 10753061]

16. Clowes RC, Rowley D. Genetic studies on small-colony variants of Escherichia coli K-12. J Gen Microbiol. 1955; 13:461-473. [PubMed: 13278497]

17. Wellinghausen N, Chatterjee I, Berger A, Niederfuehr A, Proctor RA, Kahl BC. Characterization of clinical Enterococcus faecalis small-colony variants. J Clin Microbiol. 2009; 47:2802-2811. [PubMed: 19605585]

18. Proctor RA, Kriegeskorte A, Kahl BC, Becker K, Loffler B, Peters G. Staphylococcus aureus Small Colony Variants (SCVs): a road map for the metabolic pathways involved in persistent infections. Front Cell Infect Microbiol. 2014; 4:99. [PubMed: 25120957]

19. Sendi P, Proctor RA. Staphylococcus aureus as an intracellular pathogen: the role of small colony variants. Trends Microbiol. 2009; 17:54-58. [PubMed: 19162480]

20. Sendi P, Banderet F, Graber P, Zimmerli W. Periprosthetic joint infection following Staphylococcus aureus bacteremia. J Infect. 2011; 63:17-22. [PubMed: 21663971]

21. Sendi P, Rohrbach M, Graber P, Frei R, Ochsner PE, Zimmerli W. Staphylococcus aureus small colony variants in prosthetic joint infection. Clin Infect Dis. 2006; 43:961-967. [PubMed: 16983605]

22. Kaech C, Elzi L, Sendi P, Frei R, Laifer G, Bassetti S, Fluckiger U. Course and outcome of Staphylococcus aureus bacteraemia: a retrospective analysis of 308 episodes in a Swiss tertiarycare centre. Clin Microbiol Infect. 2006; 12:345-352. [PubMed: 16524411]

23. Garcia LG, Lemaire S, Kahl BC, Becker K, Proctor RA, Denis O, Tulkens PM, Van Bambeke F. Antibiotic activity against small-colony variants of Staphylococcus aureus: review of in vitro, animal and clinical data. J Antimicrob Chemother. 2013; 68:1455-1464. [PubMed: 23485724]

24. Wakeman CA, Hammer ND, Stauff DL, Attia AS, Anzaldi LL, Dikalov SI, Calcutt MW, Skaar EP. Menaquinone biosynthesis potentiates haem toxicity in Staphylococcus aureus. Mol Microbiol. 2012; 86:1376-1392. [PubMed: 23043465]

25. Kriegeskorte A, Grubmuller S, Huber C, Kahl BC, von Eiff C, Proctor RA, Peters G, Eisenreich W, Becker K. Staphylococcus aureus small colony variants show common metabolic features in central metabolism irrespective of the underlying auxotrophism. Front Cell Infect Microbiol. 2014; 4:141. [PubMed: 25374845]

26. Kahl BC, Belling G, Becker P, Chatterjee I, Wardecki K, Hilgert K, Cheung AL, Peters G, Herrmann M. Thymidine-dependent Staphylococcus aureus small-colony variants are associated 
with extensive alterations in regulator and virulence gene expression profiles. Infect Immun. 2005; 73:4119-4126. [PubMed: 15972501]

27. Gomez-Gonzalez C, Acosta J, Villa J, Barrado L, Sanz F, Orellana MA, Otero JR, Chaves F. Clinical and molecular characteristics of infections with CO2-dependent small-colony variants of Staphylococcus aureus. J Clin Microbiol. 2010; 48:2878-2884. [PubMed: 20554819]

28. Garcia LG, Lemaire S, Kahl BC, Becker K, Proctor RA, Denis O, Tulkens PM, Van Bambeke F. Pharmacodynamic evaluation of the activity of antibiotics against hemin- and menadionedependent small-colony variants of Staphylococcus aureus in models of extracellular (broth) and intracellular (THP-1 monocytes) infections. Antimicrob Agents Chemother. 2012; 56:3700-3711. [PubMed: 22564838]

29. Sasarman A, Surdeanu M, Portelance V, Dobardzic R, Sonea S. Classification of vitamin Kdeficient mutants of Staphylococcus aureus. J Gen Microbiol. 1971; 65:125-130. [PubMed: 5089330]

30. Sasarman A, Surdeanu M, Portelance V, Dobardzic R, Sonea S. Vitamin K-deficient mutants of bacteria. Nature. 1969; 224:272. [PubMed: 5344605]

31. Kriegeskorte A, Lore NI, Bragonzi A, Riva C, Kelkenberg M, Becker K, Proctor RA, Peters G, Kahl BC. Thymidine-Dependent Staphylococcus aureus Small-Colony Variants Are Induced by Trimethoprim-Sulfamethoxazole (SXT) and Have Increased Fitness during SXT Challenge. Antimicrob Agents Chemother. 2015; 59:7265-7272. [PubMed: 26369968]

32. Sherris JC. Two small colony variants of Staph. aureus isolated in pure culture from closed infected lesions and their carbon dioxide requirements. J Clin Pathol. 1952; 5:354-355. [PubMed: 13011225]

33. McNamara PJ, Proctor RA. Staphylococcus aureus small colony variants, electron transport and persistent infections. Int J Antimicrob Agents. 2000; 14:117-122. [PubMed: 10720801]

34. Dean MA, Olsen RJ, Long SW, Rosato AE, Musser JM. Identification of point mutations in clinical Staphylococcus aureus strains that produce small-colony variants auxotrophic for menadione. Infect Immun. 2014; 82:1600-1605. [PubMed: 24452687]

35. Garcia LG, Lemaire S, Kahl BC, Becker K, Proctor RA, Tulkens PM, Van Bambeke F. Intracellular forms of menadione-dependent small-colony variants of methicillin-resistant Staphylococcus aureus are hypersusceptible to beta-lactams in a THP-1 cell model due to cooperation between vacuolar acidic $\mathrm{pH}$ and oxidant species. J Antimicrob Chemother. 2012; 67:2873-2881. [PubMed: 23002174]

36. Lannergard J, von Eiff C, Sander G, Cordes T, Seggewiss J, Peters G, Proctor RA, Becker K, Hughes D. Identification of the genetic basis for clinical menadione-auxotrophic small-colony variant isolates of Staphylococcus aureus. Antimicrob Agents Chemother. 2008; 52:4017-4022. [PubMed: 18779359]

37. von Eiff C, McNamara P, Becker K, Bates D, Lei XH, Ziman M, Bochner BR, Peters G, Proctor RA. Phenotype microarray profiling of Staphylococcus aureus menD and hemB mutants with the small-colony-variant phenotype. J Bacteriol. 2006; 188:687-693. [PubMed: 16385058]

38. Meganathan R, Kwon O. Biosynthesis of Menaquinone (Vitamin K) and Ubiquinone (Coenzyme Q). EcoSal Plus. 2009:3.

39. Meganathan R. Biosynthesis of menaquinone (vitamin K2) and ubiquinone (coenzyme Q): a perspective on enzymatic mechanisms. Vitam Horm. 2001; 61:173-218. [PubMed: 11153266]

40. Matarlo JS, Evans CE, Sharma I, Lavaud LJ, Ngo SC, Shek R, Rajashankar KR, French JB, Tan DS, Tonge PJ. Mechanism of MenE Inhibition by Acyl-Adenylate Analogues and Discovery of Novel Antibacterial Agents. Biochemistry. 2015; 54:6514-6524. [PubMed: 26394156]

41. Li X, Liu N, Zhang H, Knudson SE, Li HJ, Lai CT, Simmerling C, Slayden RA, Tonge PJ. CoA Adducts of 4-Oxo-4-Phenylbut-2-enoates: Inhibitors of MenB from the M. tuberculosis Menaquinone Biosynthesis Pathway. ACS Med Chem Lett. 2011; 2:818-823. [PubMed: 22267981]

42. Li X, Liu N, Zhang H, Knudson SE, Slayden RA, Tonge PJ. Synthesis and SAR studies of 1,4benzoxazine MenB inhibitors: novel antibacterial agents against Mycobacterium tuberculosis. Bioorg Med Chem Lett. 2010; 20:6306-6309. [PubMed: 20850304] 
43. Debnath J, Siricilla S, Wan B, Crick DC, Lenaerts AJ, Franzblau SG, Kurosu M. Discovery of selective menaquinone biosynthesis inhibitors against Mycobacterium tuberculosis. J Med Chem. 2012; 55:3739-3755. [PubMed: 22449052]

44. Kurosu M, Crick DC. MenA is a promising drug target for developing novel lead molecules to combat Mycobacterium tuberculosis. Med Chem. 2009; 5:197-207. [PubMed: 19275719]

45. Zhang YJ, Ioerger TR, Huttenhower C, Long JE, Sassetti CM, Sacchettini JC, Rubin EJ. Global assessment of genomic regions required for growth in Mycobacterium tuberculosis. PLoS Pathog. 2012; 8:e1002946. [PubMed: 23028335]

46. Li HJ, Li X, Liu N, Zhang H, Truglio JJ, Mishra S, Kisker C, Garcia-Diaz M, Tonge PJ. Mechanism of the intramolecular Claisen condensation reaction catalyzed by MenB, a crotonase superfamily member. Biochemistry. 2011; 50:9532-9544. [PubMed: 21830810]

47. Truglio JJ, Theis K, Feng Y, Gajda R, Machutta C, Tonge PJ, Kisker C. Crystal structure of Mycobacterium tuberculosis MenB, a key enzyme in vitamin K2 biosynthesis. J Biol Chem. 2003; 278:42352-42360. [PubMed: 12909628]

48. Ulaganathan V, Agacan MF, Buetow L, Tulloch LB, Hunter WN. Structure of Staphylococcus aureus1,4-dihydroxy-2-naphthoyl-CoA synthase (MenB) in complex with acetoacetyl-CoA. Acta Crystallogr. Sect. F Struct. Biol. Cryst. Commun. 2007; 63:908-913.

49. Sun Y, Song H, Li J, Li Y, Jiang M, Zhou J, Guo Z. Structural basis of the induced-fit mechanism of 1,4-dihydroxy-2-naphthoyl coenzyme A synthase from the crotonase fold superfamily. PLoS One. 2013; 8:e63095. [PubMed: 23658663]

50. Morris CM, George A, Wilson WW, Champlin FR. Effect of polymyxin B nonapeptide on daptomycin permeability and cell surface properties in Pseudomonas aeruginosa, Escherichia coli, and Pasteurella multocida. J Antibiot (Tokyo). 1995; 48:67-72. [PubMed: 7868392]

51. Vaara M. Agents that increase the permeability of the outer membrane. Microbiol Rev. 1992; 56:395-411. [PubMed: 1406489]

52. Collins MD, Jones D. Distribution of isoprenoid quinone structural types in bacteria and their taxonomic implication. Microbiol Rev. 1981; 45:316-354. [PubMed: 7022156]

53. Jeffries L, Cawthorne MA, Harris M, Diplock AT, Green J, Price SA. Distribution of menaquinones in aerobic Micrococcaceae. Nature. 1967; 215:257-259. [PubMed: 6059508]

54. Paternotte I, Fan HJ, Screve P, Claesen M, Tulkens PM, Sonveaux E. Syntheses and hydrolysis of basic and dibasic ampicillin esters tailored for intracellular accumulation. Bioorg Med Chem. 2001; 9:493-502. [PubMed: 11249141]

55. Moreira R, Calheiros T, Cabrita J, Mendes E, Pimentel M, Iley J. Acyloxymethyl as a drug protecting group. Part 3. Tertiary O-amidomethyl esters of penicillin $\mathrm{G}$ : chemical hydrolysis and anti-bacterial activity. Pharm Res. 1996; 13:70-75. [PubMed: 8668682]

56. Lu X, Zhou R, Sharma I, Li X, Kumar G, Swaminathan S, Tonge PJ, Tan DS. Stable analogues of OSB-AMP: potent inhibitors of MenE, the o-succinylbenzoate-CoA synthetase from bacterial menaquinone biosynthesis. Chembiochem. 2012; 13:129-136. [PubMed: 22109989]

57. Wiegand I, Hilpert K, Hancock RE. Agar and broth dilution methods to determine the minimal inhibitory concentration (MIC) of antimicrobial substances. Nat Protoc. 2008; 3:163-175. [PubMed: 18274517]

58. Akinleye A, Chen Y, Mukhi N, Song Y, Liu D. Ibrutinib and novel BTK inhibitors in clinical development. J Hematol Oncol. 2013; 6:59. [PubMed: 23958373]

59. Honigberg LA, Smith AM, Sirisawad M, Verner E, Loury D, Chang B, Li S, Pan Z, Thamm DH, Miller RA, Buggy JJ. The Bruton tyrosine kinase inhibitor PCI-32765 blocks B-cell activation and is efficacious in models of autoimmune disease and B-cell malignancy. Proc Natl Acad Sci U S A. 2010; 107:13075-13080. [PubMed: 20615965]

60. Evans EK, Tester R, Aslanian S, Karp R, Sheets M, Labenski MT, Witowski SR, Lounsbury H, Chaturvedi P, Mazdiyasni H, Zhu Z, Nacht M, Freed MI, Petter RC, Dubrovskiy A, Singh J, Westlin WF. Inhibition of Btk with CC-292 provides early pharmacodynamic assessment of activity in mice and humans. J Pharmacol Exp Ther. 2013; 346:219-228. [PubMed: 23709115]

61. Serafimova IM, Pufall MA, Krishnan S, Duda K, Cohen MS, Maglathlin RL, McFarland JM, Miller RM, Frodin M, Taunton J. Reversible targeting of noncatalytic cysteines with chemically tuned electrophiles. Nat Chem Biol. 2012; 8:471-476. [PubMed: 22466421] 
62. Bradshaw JM, McFarland JM, Paavilainen VO, Bisconte A, Tam D, Phan VT, Romanov S, Finkle D, Shu J, Patel V, Ton T, Li X, Loughhead DG, Nunn PA, Karr DE, Gerritsen ME, Funk JO, Owens TD, Verner E, Brameld KA, Hill RJ, Goldstein DM, Taunton J. Prolonged and tunable residence time using reversible covalent kinase inhibitors. Nat Chem Biol. 2015; 11:525-531. [PubMed: 26006010]

63. White DC, Frerman FE. Extraction, characterization, and cellular localization of the lipids of Staphylococcus aureus. J Bacteriol. 1967; 94:1854-1867. [PubMed: 4965365]

64. Onorato JM, Chen L, Shipkova P, Ma Z, Azzara AV, Devenny JJ, Liang N, Haque TS, Cheng D. Liquid-liquid extraction coupled with LC/MS/MS for monitoring of malonyl-CoA in rat brain tissue. Anal Bioanal Chem. 2010; 397:3137-3142. [PubMed: 20549491]

65. Keshishian H, Addona T, Burgess M, Kuhn E, Carr SA. Quantitative, multiplexed assays for low abundance proteins in plasma by targeted mass spectrometry and stable isotope dilution. Mol Cell Proteomics. 2007; 6:2212-2229. [PubMed: 17939991]

66. Addona TA, Abbatiello SE, Schilling B, Skates SJ, Mani DR, Bunk DM, Spiegelman CH, Zimmerman LJ, Ham AJ, Keshishian H, Hall SC, Allen S, Blackman RK, Borchers CH, Buck C, Cardasis HL, Cusack MP, Dodder NG, Gibson BW, Held JM, Hiltke T, Jackson A, Johansen EB, Kinsinger CR, Li J, Mesri M, Neubert TA, Niles RK, Pulsipher TC, Ransohoff D, Rodriguez H, Rudnick PA, Smith D, Tabb DL, Tegeler TJ, Variyath AM, Vega-Montoto LJ, Wahlander A, Waldemarson S, Wang M, Whiteaker JR, Zhao L, Anderson NL, Fisher SJ, Liebler DC, Paulovich AG, Regnier FE, Tempst P, Carr SA. Multi-site assessment of the precision and reproducibility of multiple reaction monitoring-based measurements of proteins in plasma. Nat Biotechnol. 2009; 27:633-641. [PubMed: 19561596]

67. Alexander EL, Gardete S, Bar HY, Wells MT, Tomasz A, Rhee KY. Intermediate-type vancomycin resistance (VISA) in genetically-distinct Staphylococcus aureus isolates is linked to specific, reversible metabolic alterations. PLoS One. 2014; 9:e97137. [PubMed: 24817125]

68. Nandakumar M, Prosser GA, de Carvalho LP, Rhee K. Metabolomics of Mycobacterium tuberculosis. Methods Mol Biol. 2015; 1285:105-115. [PubMed: 25779312]

69. Melter O, Radojevic B. Small colony variants of Staphylococcus aureus--review. Folia Microbiol (Praha). 2010; 55:548-558. [PubMed: 21253898]

70. Meganathan R. Biosynthesis of menaquinone (vitamin K-2) and ubiquinone (coenzyme Q): A perspective on enzymatic mechanisms. Vitam. Horm. 2001; 61:173-218. [PubMed: 11153266]

71. Jiang M, Chen X, Guo Z-F, Cao Y, Chen M, Guo Z. Identification and Characterization of (1R, 6R)-2-Succinyl-6-hydroxy-2,4-cyclohexadiene-1-carboxylate Synthase in the Menaquinone Biosynthesis of Escherichia coli. Biochemistry. 2008; 47:3426-3434. [PubMed: 18284213]

72. Widhalm JR, van Oostende C, Furt F, Basset GJ. A dedicated thioesterase of the Hotdog-fold family is required for the biosynthesis of the naphthoquinone ring of vitamin K1. Proc Natl Acad Sci U S A. 2009; 106:5599-5603. [PubMed: 19321747]

73. Chen M, Ma X, Chen X, Jiang M, Song H, Guo Z. Identification of a hotdog fold thioesterase involved in the biosynthesis of menaquinone in Escherichia coli. J Bacteriol. 2013; 195:27682775. [PubMed: 23564174]

74. Hiratsuka T, Furihata K, Ishikawa J, Yamashita H, Itoh N, Seto H, Dairi T. An alternative menaquinone biosynthetic pathway operating in microorganisms. Science. 2008; 321:1670-1673. [PubMed: 18801996] 

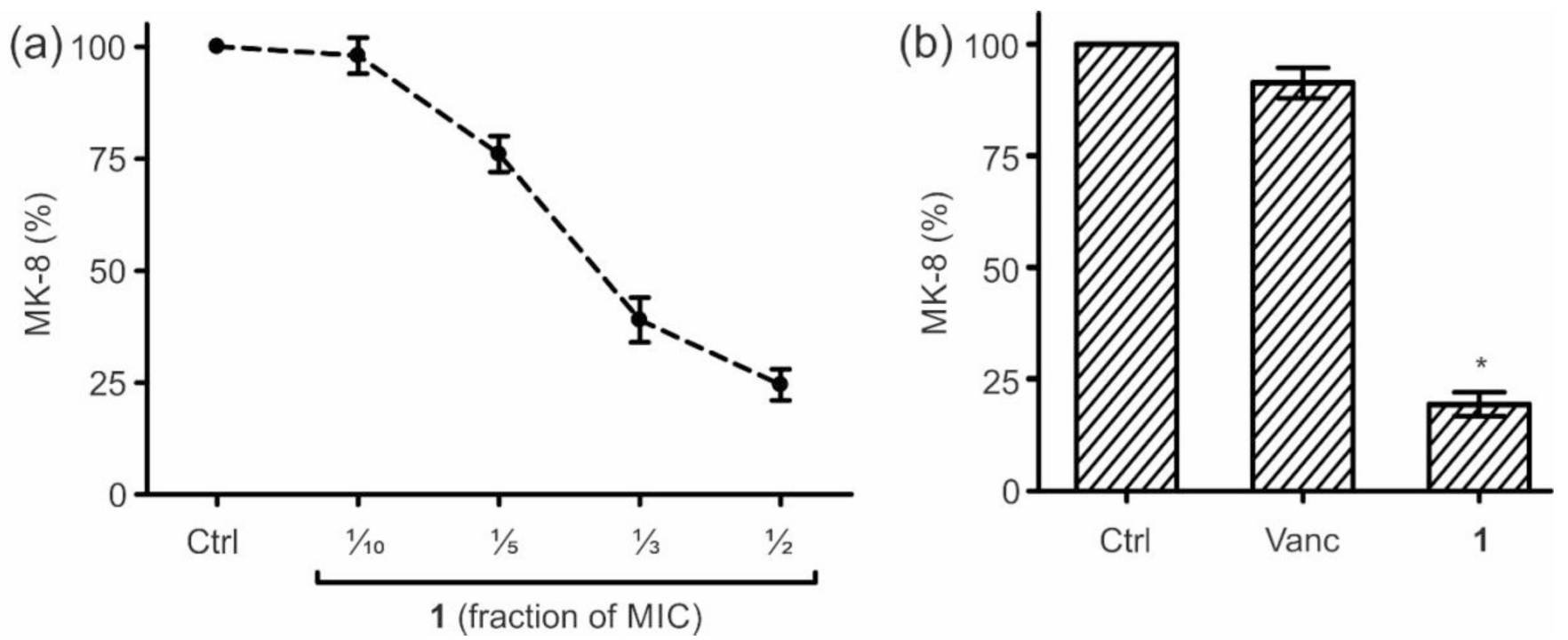

Figure 1. Menaquinone-8 (MK-8) quantification in MRSA cells treated with 1

(a) Change in MK-8 levels determined in MRSA treated with sub-MICs $(1 / 10,1 / 5,1 / 3$, and $1 / 2 \mathrm{MIC})$ of $1(\mathrm{MIC}=0.75 \mu \mathrm{g} / \mathrm{mL})$. A $75 \%$ decrease in MK-8 is seen at $1 / 2 \mathrm{MIC}$. (b) MRSA treated with vancomycin $(2 \mu \mathrm{g} / \mathrm{mL})$ and $\mathbf{1}(0.38 \mu \mathrm{g} / \mathrm{mL})$. Treatment with vancomycin and $\mathbf{1}$ resulted in a $10 \%$ and $75 \%$ decrease in MK-8 levels, respectively. Ctrl (control) are untreated cells. $* \mathrm{p}<0.01$. 


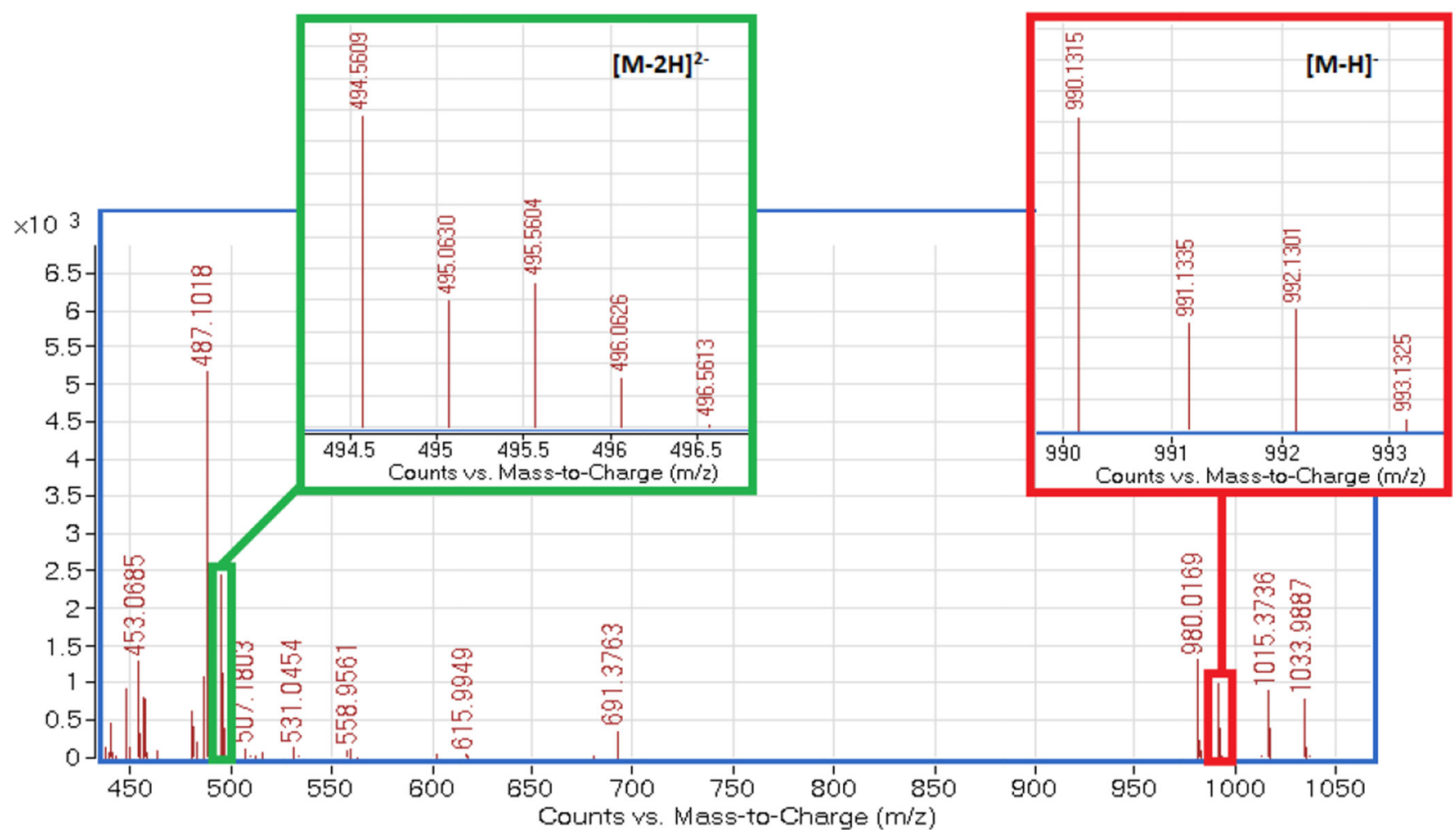

Figure 2. Formation of CoA Adduct 8 in MRSA Cells Treated with 1

High Resolution LC/UV/MS spectrum of an extract from MRSA cells treated with $8 \mu \mathrm{g} / \mathrm{mL}$

of $\mathbf{1}$. Found-by-Formula (FBF) search clearly indicates the presence of $\mathbf{8}$, which is the CoA adduct of $\mathbf{1}(\mathrm{m} / z=991.1329)$ but not of 7 , which is the CoA adduct of the corresponding acid $(6)(\mathrm{m} / Z=977.1235)$. Observed peaks correspond to $8[\mathrm{M}-\mathrm{H}]=990.1315$ and $[\mathrm{M}-2 \mathrm{H}]^{-2}=494.5608$. The inset (red and green box) shows isotopic distribution of ${ }^{35} \mathrm{Cl} /{ }^{37} \mathrm{Cl}$ present in 8 with calculated relative abundance of $\mathrm{m} / z$ ions $=100,39,48$, and $16 \%$ respectively among the 4 peaks shown for $[\mathrm{M}-\mathrm{H}]$ (see Table S1 for complete analysis of theoretical and observed isotopic distribution). Y-axis is relative intensity and $\mathrm{x}$-axis is Counts vs. Mass-to-Charge $(\mathrm{m} / z)$. 

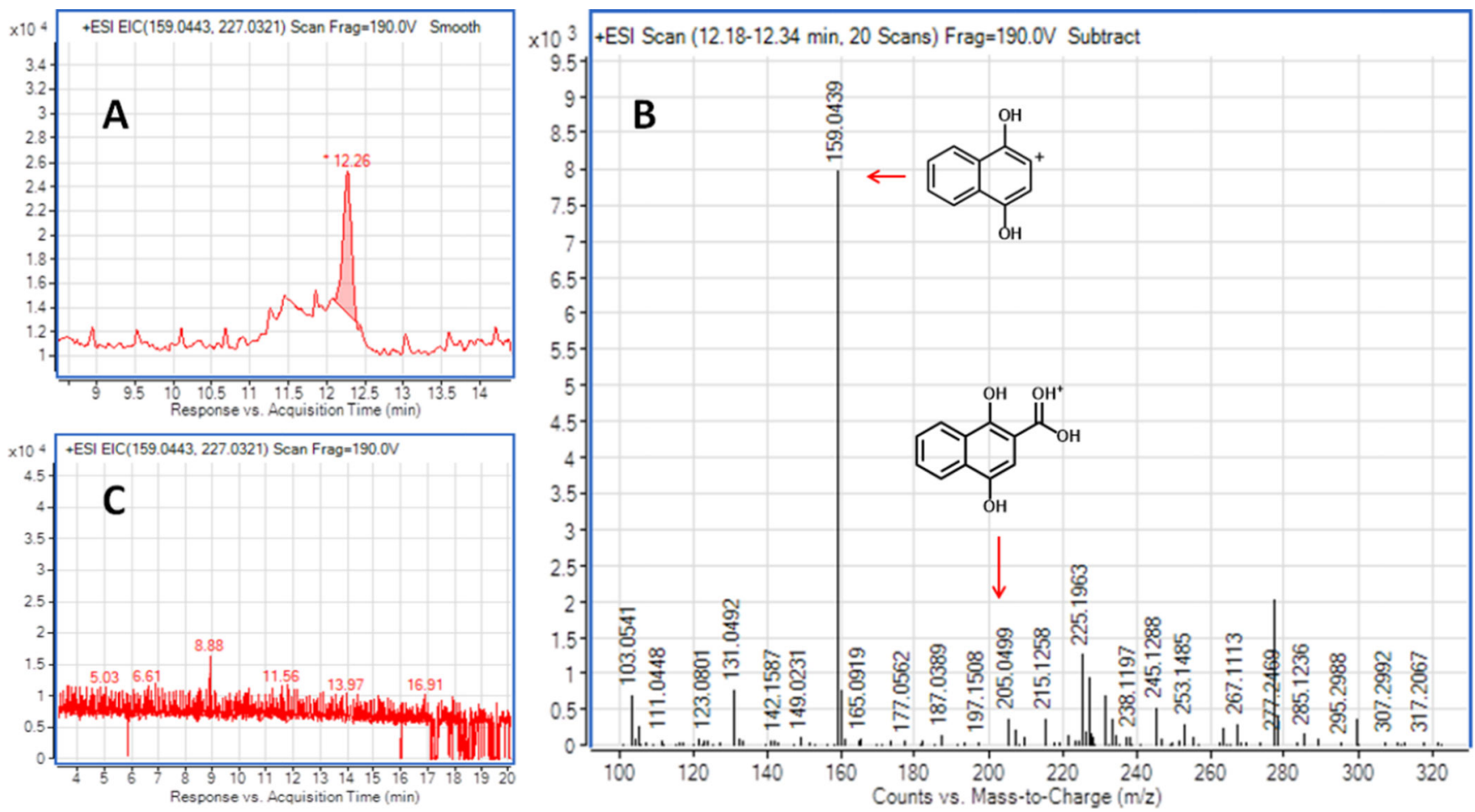

Figure 3. Effect of 1 on the Level of DHNA in MRSA cells

High resolution LC/UV/MS spectra of untreated cells and cells treated with $8 \mu \mathrm{g} / \mathrm{mL}$ of $\mathbf{1}$.

Commercially available DHNA has a retention time of $12.22 \mathrm{~min}$ with $[\mathrm{M}+\mathrm{H}]^{+}=205.0499$ and also $\mathrm{m} / z=227.0321,[\mathrm{M}+\mathrm{Na}]^{+}, \mathrm{m} / z=159.0443\left(\right.$ loss of $\mathrm{CO}_{2}$ ), $\mathrm{m} / z=131.0493$ (CO loss) and 103.0546 (CO loss) (see Figure S6 for analysis of commercially available DHNA). (A) In untreated cells, a peak is observed with a retention time of $12.26 \mathrm{~min}$. (B) The mass spectrum of the peak $12.26 \mathrm{~min}$ is consistent with DHNA: $\mathrm{ESI}^{+}=205.0499,159.0439$, 131.049 and 103.055. (C) Using the same protocol, no evidence of DHNA is seen in cells treated with 1. 
$24 \mathrm{hrs}$
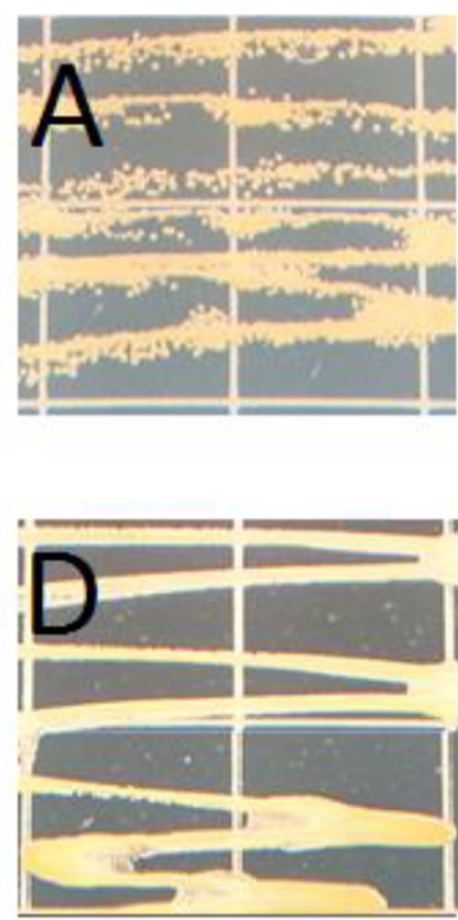

$48 \mathrm{hrs}$
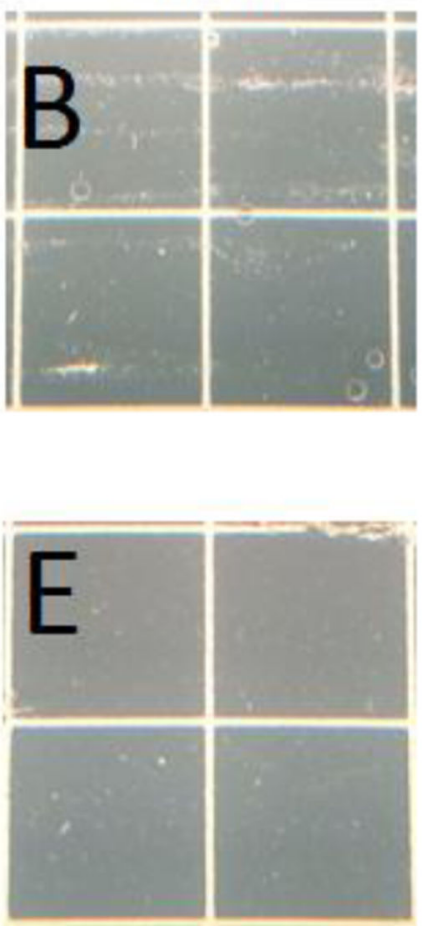

$72 \mathrm{hrs}$
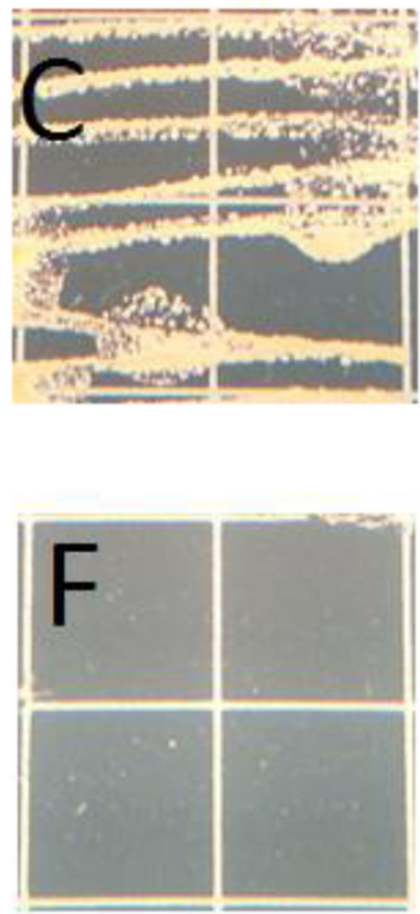

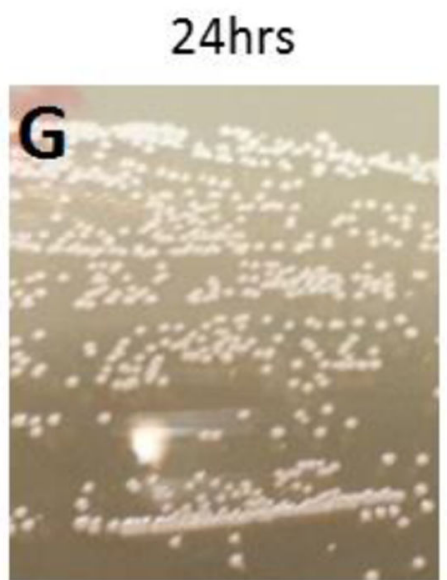

WT-MRSA
$48 \mathrm{hrs}$

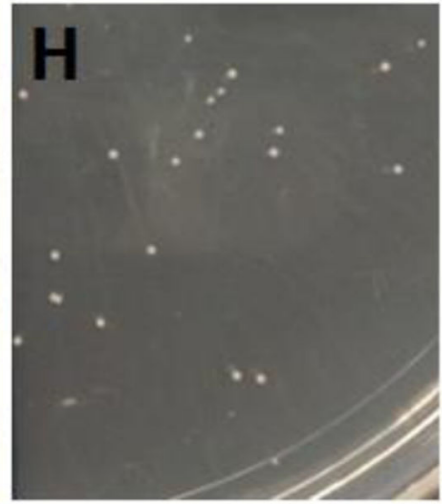

menB-

Figure 4. SCV formation following treatment of MRSA cells with 1 or by knocking out menB A) The normal growth phenotype of wt MRSA cells showing defined individual colonies after $24 \mathrm{hr}$ at $37{ }^{\circ} \mathrm{C}$. B) MRSA plated on TSA containing $4 \mu \mathrm{g} / \mathrm{mL} 1$ and incubated for $48 \mathrm{hr}$ shows SCV morphology that leads to overgrowth after $72 \mathrm{hr}(\mathbf{C})$. D) MRSA plated on TSA containing $16 \mu \mathrm{g} / \mathrm{mL} 1$ (2x MIC) and $10 \mu \mathrm{g} / \mathrm{mL} \mathrm{MK}-4$. This plate shows over growth after $24 \mathrm{hr}$ incubation, indicating that MK complements the antibacterial activity of 1. E) and F) show no growth even after $72 \mathrm{hr}$ incubation on TSA with $8 \mu \mathrm{g} / \mathrm{mL} \mathrm{1}$, making this concentration the agar-MIC. G) and $\mathbf{H}$ ) compares $S$. aureus growth upon knockout of the 
menB gene. ${ }^{24}$ Consistent with other studies, the $m e n B^{-/}$strain ${ }^{24}$ forms SCVs characterized by loss of pigmentation and small/slow growing colonies. 


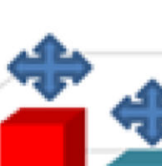

\section{MD $\quad$ MK-4 $\quad$ MK-5 $\quad$ MK-6 $\quad$ MK-7 $\quad$ MK-8 $\quad$ MK-9}

\section{Menaquinones}

Figure 5.

Menaquinone (MK) quantification in MRSA cells treated with $\mathbf{1}$ and supplemented with menaquinone-4 (MK-4) or menadione (MD). Untreated cells show a distribution of MKs that vary in the length of the polyisoprene chain and in which MK-8 is the dominant species. Treatment with $1(0.38 \mu \mathrm{g} / \mathrm{mL})$ results in a decrease in all MK species. Cells supplemented with MD $(10 \mu \mathrm{M})$ but not MK-4 $(10 \mu \mathrm{M})$ recover the MK distribution observed in untreated cells. This indicates that MD may act as a substrate for MK biosynthesis downstream of the enzyme inhibited by $\mathbf{1}$. Presumably MK4 directly replaces the function of MK-8 and the other major MK species in the electron transport chain. Since MK-4 and MD were supplemented at $10 \mu \mathrm{M}$, the levels of these molecules were $>400 \%$ relative to MK- 8 levels in untreated cells. 
(a)

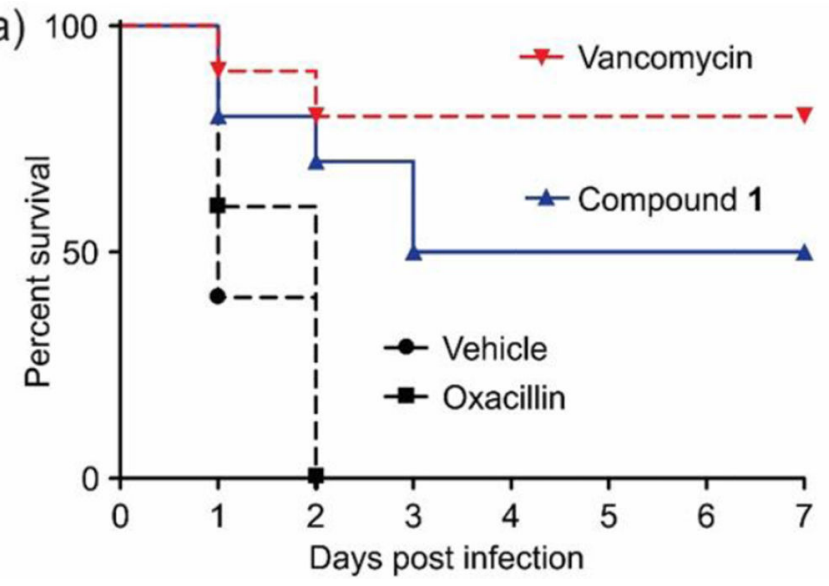

(b)

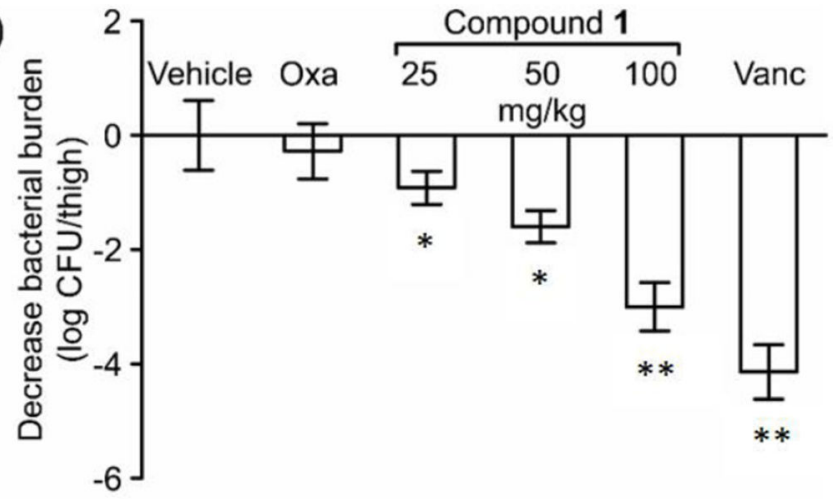

Figure 6. In vivo antibacterial efficacy of compound 1 against MRSA

(a) Survival of infected mice treated with vehicle $(\boldsymbol{O}, \mathrm{n}=5)$, oxacillin $(100 \mathrm{mg} / \mathrm{kg}, \boldsymbol{\square}, \mathrm{n}=5)$, compound $\mathbf{1}(100 \mathrm{mg} / \mathrm{kg}, \mathbf{\Delta}, \mathrm{n}=10)$ or vancomycin $(100 \mathrm{mg} / \mathrm{kg}, \boldsymbol{\nabla}, \mathrm{n}=10)$. (b) Decrease of bacterial burden in thigh muscle after treatment with vehicle (n=3), oxacillin (Oxa, 100 $\mathrm{mg} / \mathrm{kg}, \mathrm{n}=3$ ), compound $\mathbf{1}$ (25, 50 and $100 \mathrm{mg} / \mathrm{kg}, \mathrm{n}=5$ ), and vancomycin (Vanc, $100 \mathrm{mg} / \mathrm{kg}$, $\mathrm{n}=3$ ). Statistical significance was determined using a one tail T-test where $* \mathrm{p}<0.05$ and $* *$ $\mathrm{p}<0.005$. 
<smiles>C=C(O[C@@H]1C=C(C(=O)[O-])C=C[C@H]1O)C(=O)[O-]</smiles>

Chorismate

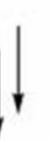

Menaqunione Biosynthesis<smiles>CC(C)C(=O)SC(=O)CCC(=O)c1ccccc1C(=O)[O-]</smiles>

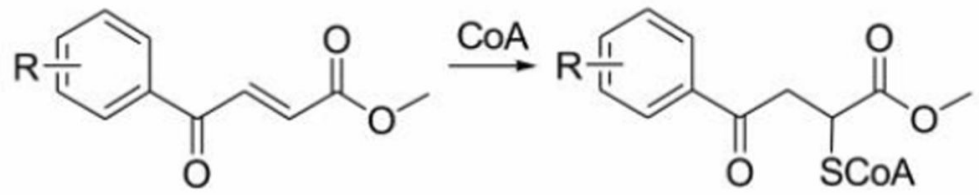

CoA Adduct<smiles>CC(C)=CCc1c(C)c(O)c2ccccc2c1O</smiles>

Menaquinone $\mathrm{n}=4-9$ : MK4-MK9

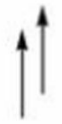

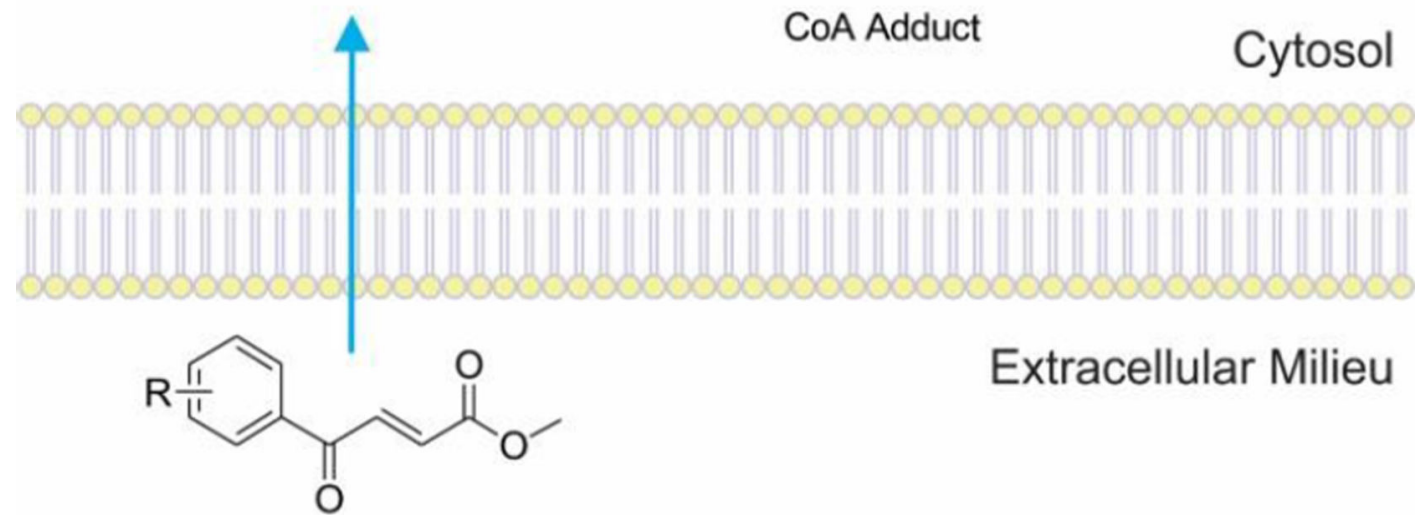

\section{4-oxo-4-phenylbut-2-enoyl methyl ester}

Figure 7.

Proposed mode of action of the 4-oxo-4-phenyl-2-butenoyl methyl esters. Upon penetration into the cell, the corresponding CoA adduct is formed, leading to inhibition of MenB and a decrease in the levels of DHNA and MK. 


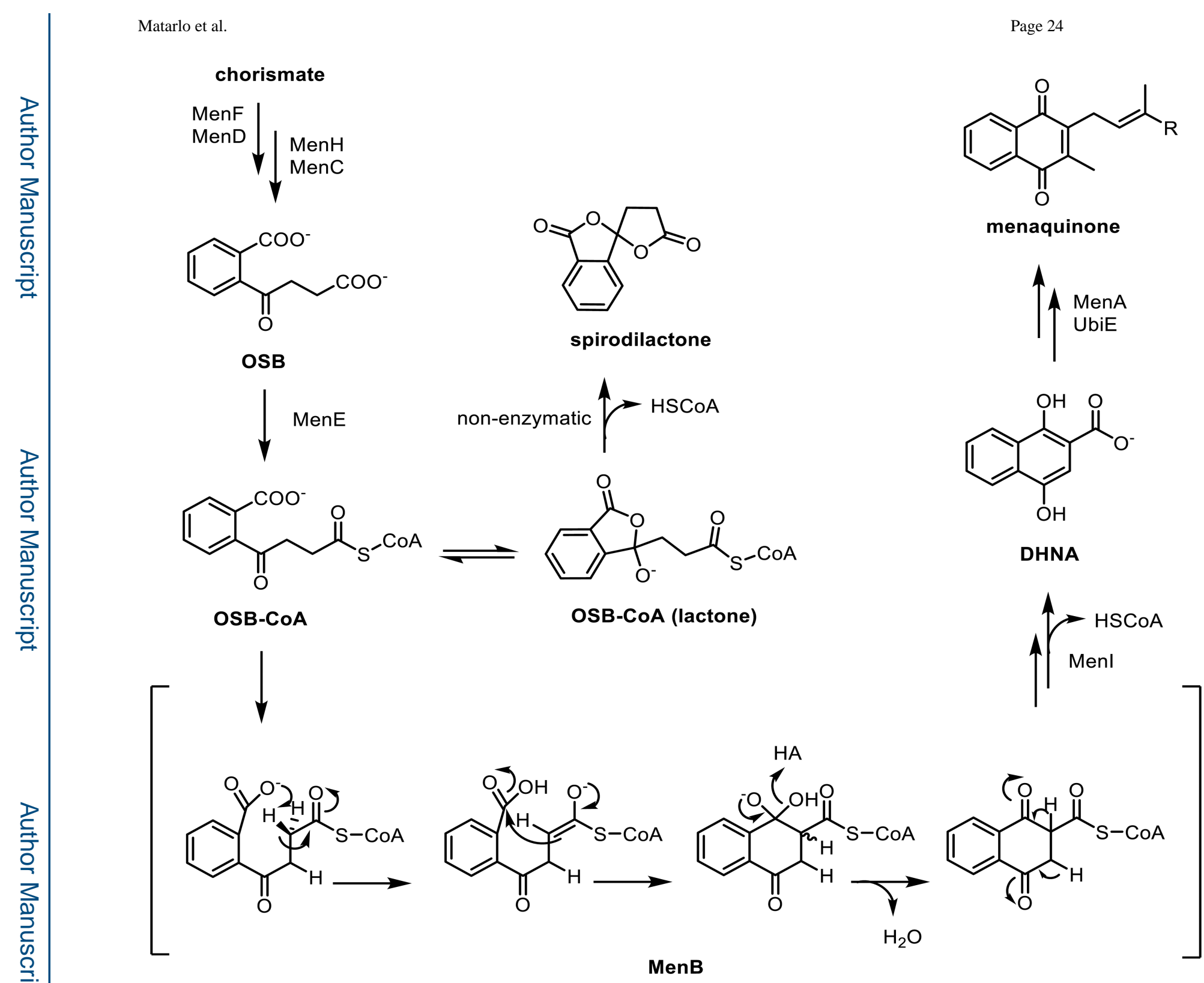

Scheme 1.

The classical pathway for menaquinone (MK) biosynthesis in organisms such as $S$. aureus, E. coli, and M. tuberculosis showing the reaction catalyzed by MenB. Original details of this pathway are summarized in Meganathan, 2001. ${ }^{70}$ More recently, it has been shown that MenH converts SEPHCHC to SHCHC (SHCHC synthase). ${ }^{71}$ In addition, a dedicated DHNA-CoA thioesterase (MenI) has been identified in phylloquinone (vitamin K1) biosynthesis, $^{72}$ and a bacterial homolog of this enzyme has potentially been identified in $E$. coli ${ }^{73}$ The classical pathway is distinct from the pathway that proceeds via futalosine in Streptomyces ${ }^{74}$ Also shown is the non-enzymatic decomposition of OSB-CoA to spirodilactone. 
Table 1

In vitro antibacterial activity of the 4-oxo-4-phenyl-2-butenoic acids and methyl esters against $S$. aureus.

Compound
$\begin{aligned} & \text { MIC }(\mu \mathrm{g} / \mathbf{m L})^{\boldsymbol{a}} \\ & \mathbf{M}\end{aligned}$
$\mathbf{M}$




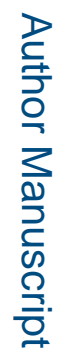
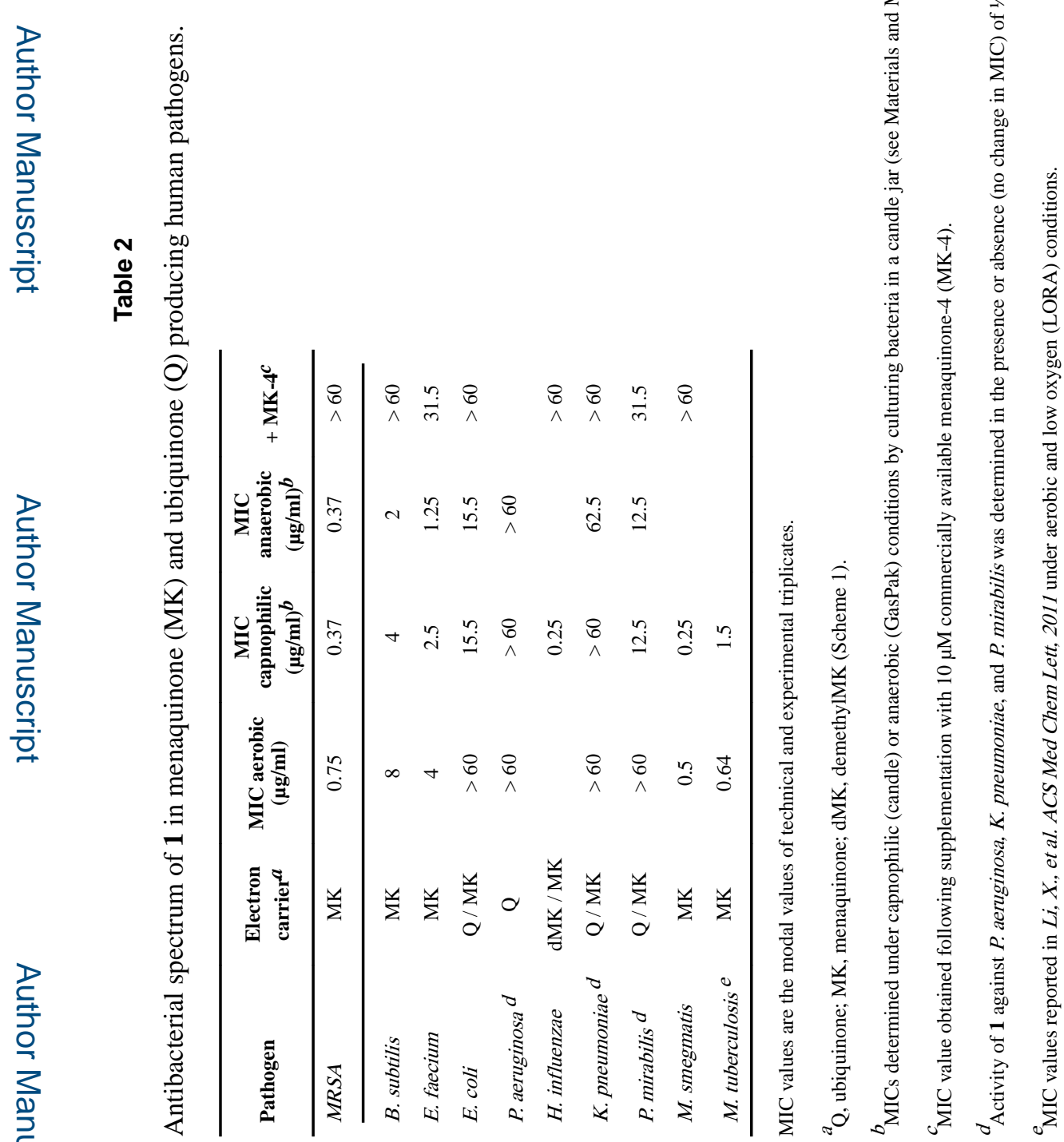

ACS Infect Dis. Author manuscript; available in PMC 2017 May 13. 
Table 3

Thermodynamic Constants for the Binding of CoA and the CoA Adducts of 1 and 6 to saMenB

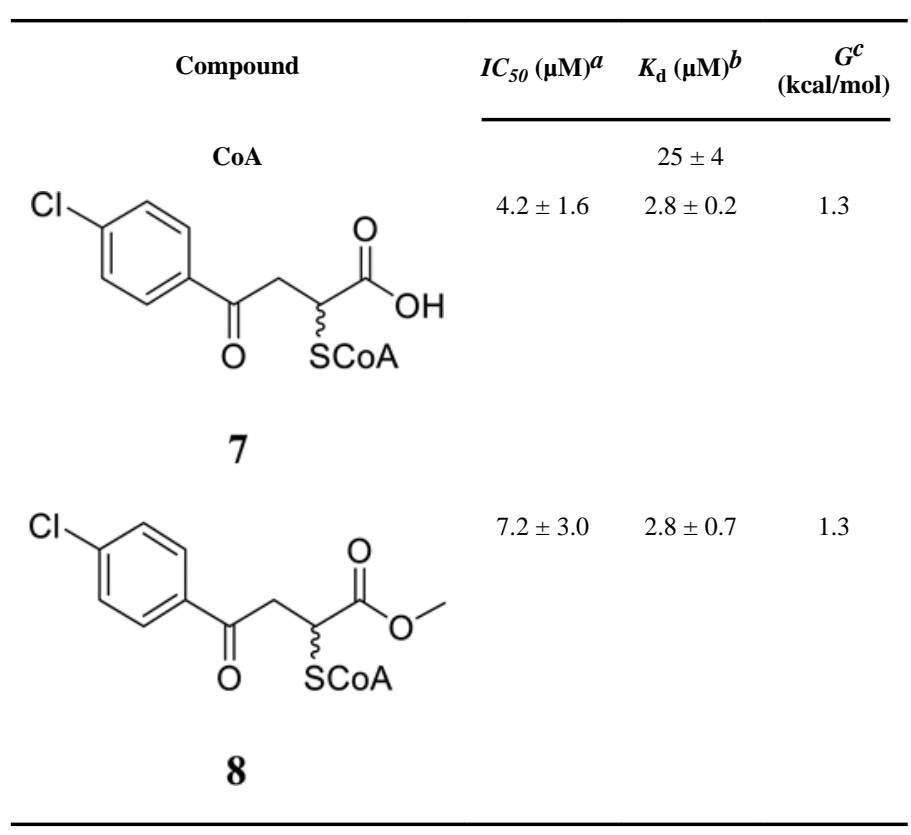

${ }^{a} I_{50}$ values were determined using the MenE-MenB coupled assay where MenB was rate limiting. In contrast, no inhibition was observed with concentrations of up to $50 \mu \mathrm{M}$ of $\mathbf{7}$ or $\mathbf{8}$ when MenE was rate limiting in the coupled assay.

$b_{K_{\mathrm{d}}}$ values for the interaction of compounds with $s a \mathrm{MenB}$ were determined using isothermal titration calorimetry (ITC). In contrast, no binding could be detected with up to $200 \mu \mathrm{M}$ of $\mathbf{7}$ or $\mathbf{8}$ when ITC was used to analyze the interaction of the compounds with MenE.

${ }^{c} \Delta \Delta G$ was determined by calculating $\Delta G$ of compound binding vs $\Delta G$ of CoA binding (see Table S2 for complete thermodynamic values). All IC 50 measurements were performed in triplicate and ITC experiments were performed in duplicate. 